$$
\begin{gathered}
S D 401 \\
F 8
\end{gathered}
$$


F 8 
SD 401

F8

Copy 1

\title{
FOREST NURSERIES AND NURSERY METHODS
}

\section{IN EUROPE}

\author{
BY \\ WILLIAM F. FOX
}

\begin{abstract}
Reprinted frem the Eighth and Ninth Reports of the Forest, Fish and Game Commission, State of New York
\end{abstract}

J. B. LYON COMPANY, STATE PRINTERS

ALBANY, NEW YORK 


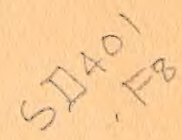

$$
\begin{gathered}
\text { D. OF D } \\
m^{r} 22 \cdot 908
\end{gathered}
$$

$$
\because \vdots \vdots
$$





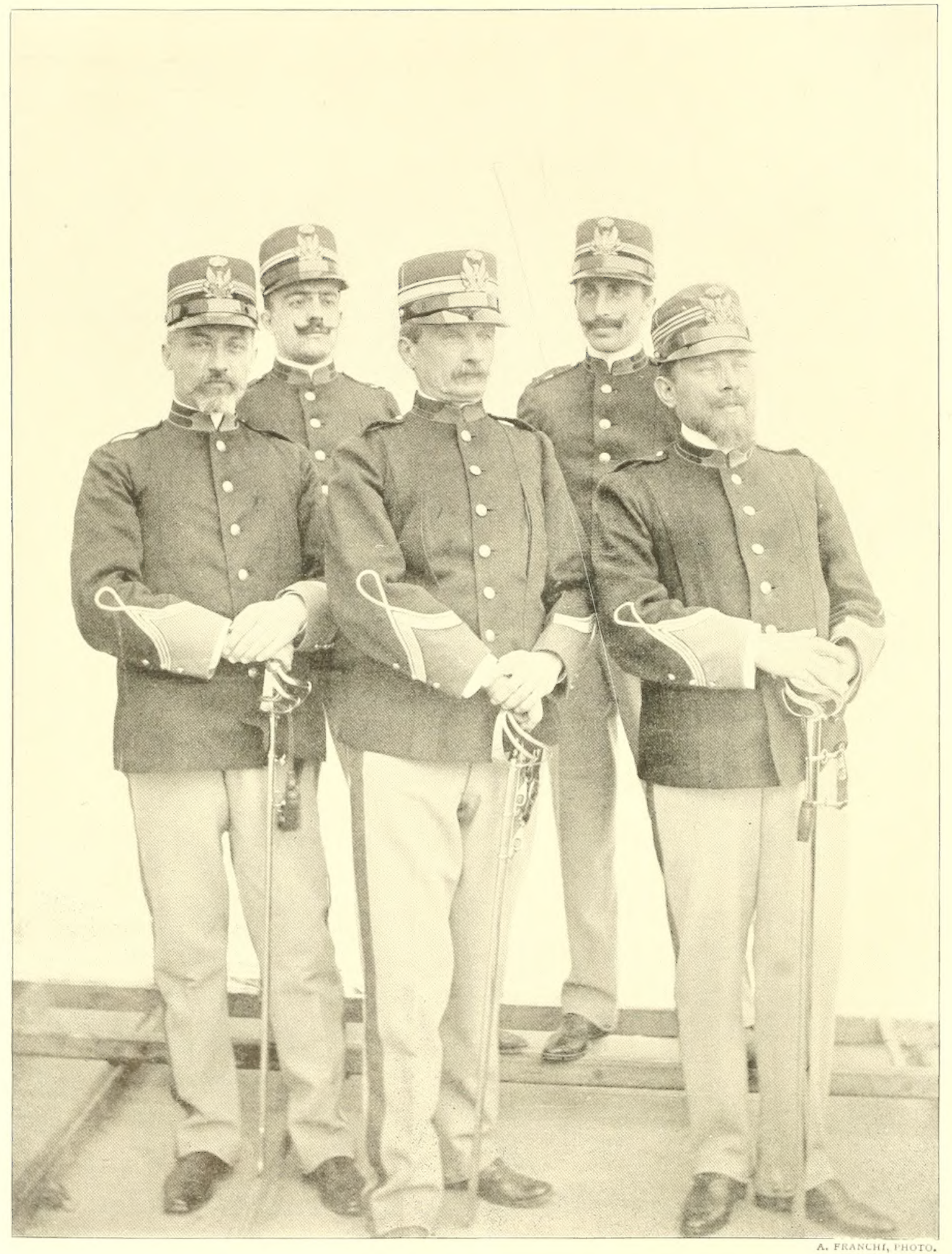

ITALIAN FORESTERS. 


\title{
Forest Narseries and Narserv Methods in Earope
}

\author{
By William F. Fox.
}

\section{Introdactory.}

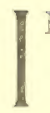

The management of American forests the time has come when it would seem evident to all interested in the work that the future timber supply in many localities is dependent on reforestation. But natural reforestation is unsatisfactory from the forester's point of view. In results it falls short, by far, of the maximum in quantity and quality of merchantable timber which a given area can be made to yield through proper methods of silvicultural work.

The highly satisfactory results attained from planted forests in Europe, where this practice has been followed for two centuries or more, justifies clearly the adoption of this system in America. The New Forest in England was "afforested" by order of William the Conqueror, in 1079, and since then reforestation has heen practiced from time to time in European countries, until cultivated forests are now the rule rather than the exception. Throughout Germany, France, Belgium and Italy most of the wooded areas show high forests of a density and regularity that indicate plainly their artificial growth. For these and other reasons the planting of forests is engaging the attention of American foresters to-day. It is no new idea.

A planted forest, like the primitive one, is grown from seed, but in the former the dissemination is under intelligent control. This may be done by broadcast sowing, by the seed-spot method, or by the intermediate process of raising small seedlings in garden or nursery beds; and, large areas of trees are propagated from wind-sown seeds, skilfully directed and managed.

Broadcast sowing may be a desirable method under certain conditions-where economy is necessary, where a supply of seedling plants cannot be obtained conveniently, or where a rocky, uneven surface, covered with a scrubby growth, compels its use. But it has the disadvantages of uncertanty. irregularity and the subsequent expense of filling in the blanks where seeds falled to germinate. As the planting of seedlings at regular intervals gives the forester better control 
of his future work, this plan is in general use abroad. It necessitates, however, the establishment of nurseries for the propagation of the young plants.

The management of tree nurseries, in connection with forest plantations, has been carried on for so many years in Europe that the American forester who is about to engage in this branch of silvicultural work will find there an ample field in which to study and gain the information available for similar efforts. These nurseries will be found in most of the forest regions abroad - the baumschule in Germany, the pepiniere in France, and the piantonaio in Italy. The object of these pages is to describe briefly, but as plainly as possible, the technical methods employed in the forest nurseries of various European countries.

For this purpose the descriptions are confined to certain ones in which the construction and management are fairly typical of the others in that particular country. To attempt more would involve needless repetition and unnecessarily extend the scope and province of this article.

\section{Italy.}

We have heard so much of German forestry and its superior methods that our American foresters, when they go abroad for study and information, are too apt to devote their time exclusively to travel within Germany. It would be well if, when not limited as to time or expense, they were to extend their observations to some of the other continental forests and nurseries. But few of our foresters seem to have paid any attention to Italy. This may be due to the small percentage of woodlands in that country. But the Italian Government is steadily increasing its forest areas, and is conducting silvicultural operations of a high order.

The nurseries have an annual output of about 9,000,000 plants, and new plantations of large areas are made each year. The surplus seedlings, or transplants, not necessary for fieldwork are distributed free to persons who may need them in reforesting private lands.

The location, area and product of the various nurseries maintained by the Italian Government are as follows:

\begin{tabular}{|c|c|c|c|c|c|c|c|c|c|c|c|c|c|c|c|}
\hline \multicolumn{7}{|c|}{ PROVINCE. } & \multicolumn{6}{|c|}{ Name of the forest nursery. } & \multirow{2}{*}{$\begin{array}{c}\begin{array}{c}\text { Area in } \\
\text { hectares.* }\end{array} \\
5.4538\end{array}$} & \multirow{2}{*}{$\begin{array}{c}\begin{array}{c}\text { Yearly } \\
\text { expenditure for } \\
\text { maintenance. }\end{array} \\
\text { Francs. } \\
6,538.25\end{array}$} & \multirow{2}{*}{$\begin{array}{c}\begin{array}{c}\text { Number of } \\
\text { plants } \\
\text { produced. }\end{array} \\
\text { I, } 000,000\end{array}$} \\
\hline Firenze & . & - & . & - & . & . & Vallombrosa. & . & . & . & . & . & & & \\
\hline Arezzo & . & - & - & - & . & . & Camaldoli . & . & . & $\cdot$ & $\cdot$ & - & $7 \cdot 3354$ & $6,203.00$ & 800,000 \\
\hline Firenze & . & - & - & . & . & . & Boscolungo. & . & $\cdot$ & " & $\cdot$ & $\cdot$ & 2.9605 & $2,978.40$ & 600,000 \\
\hline Belluno & . & - & - & - & . & . & Pian Spini & . & & $\cdot$ & $\cdot$ & . & 2.9836 & $3,071.76$ & $1,200,000$ \\
\hline Bergamo & . & . & . & . & . & " & Pradoni & . & & . & . & . & I. 6022 & 669.18 & I 40,000 \\
\hline
\end{tabular}




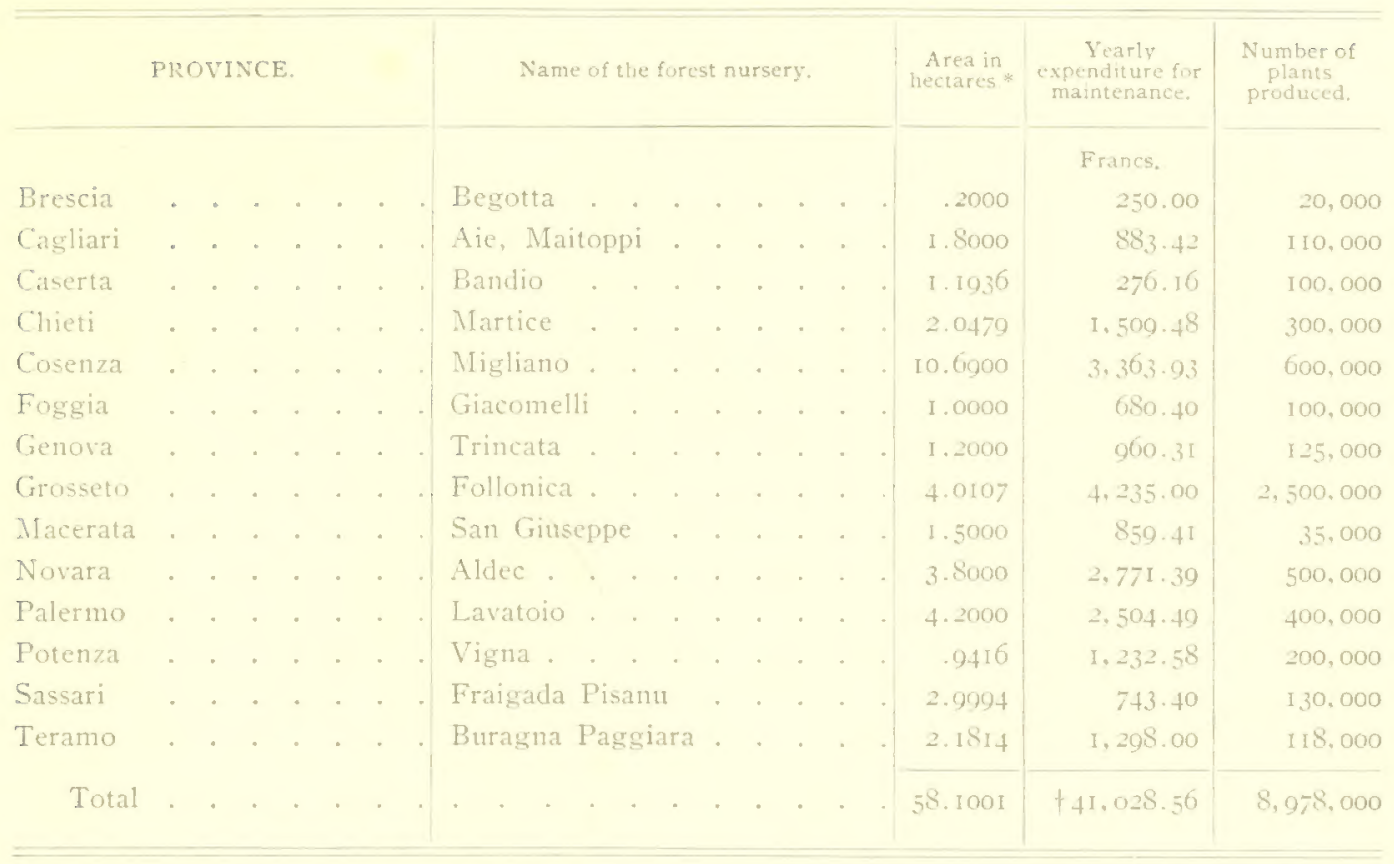

* A hectare is equal to $2.47 \mathrm{I}$ acres. fOr, $\$ 7.795 .43$.

The above statement will give some idea of the large extent to which nurseries are used by European governments in their work of forest extension. In Germany and France the nurseries are much more numerous, owing to the larger area of forest, greater amount of timber cutting, and more extensive replanting.

The different species of trees propagated in these Italian nurseries are shown in the following list, which was kindly furnished by Inspector A Franchi, of the Forestry Department of Tuscany. The botanical designations, some of which are not used in this country, are as given in his list, and include some species which are rare in America:

Silver fir . . . . . Abies alba Willd. (Pinus picea Linn,)

Norway spruce . . . . Abies picea Willd. (Pinus abies Linn.)

Norway maple. . . . . Acer platanoides Linn

Sycamore maple . . . . . Acer pseudo-platanus Linn.

European alder . . . . Alnus glutinosa Gaertn.

Speckled alder . . Alnus incana Willd.

Chestnut . . . . . . Fagus castanea Linn.

Beech . . . . . . . Fagus syluatica Linn.

European ash . . . . Fraxinus excelsior Linn.

Flowering ash. . . . . Fraximus ormus Linn.

Walnut . . . . . Juglans regia Linn. 


\begin{tabular}{|c|c|c|c|c|c|}
\hline Larch . · & - & - & - & & Larix europaea Dec. \\
\hline Austrian pine & . . & . & ${ }^{\circ}$ & & - Pinus austriaca Reich. \\
\hline Aleppo pine & 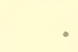 & . & . & . & Pinus halepensis Mill. \\
\hline Corsican pine & . . & . & & . & - Pinus laricio Poir. \\
\hline Maritime pine & . . & . & . & " & - Pinus pinaster Ait. \\
\hline Stone pine & . . & • & . & . & - Pinus pinea Linn \\
\hline Scotch pine & . . & . & . & . & - Pinus sylvestris Linn. \\
\hline Turkey oak & . . & & - & . & - Quercus cerris Linn. \\
\hline Holly or evers & reen & oal & & ${ }^{\circ}$ & - Quercus ilex Linn. \\
\hline English oak & . & & & . & - Quercus robur Linn. \\
\hline Siberian oak & . . & & . & 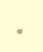 & - Quercus sessiliflora Smith. \\
\hline Cork oak & . . & . & . & . & - Quercus suber Linn. \\
\hline Locust & . & . & & - & Robinia pseudo-acacia Linn. \\
\hline Basswood & . & . & . & 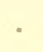 & Tilia grandifolia Smith. \\
\hline English elm & . . & . & & . & - Ulmus campestris Linn \\
\hline Cypress & . . & . & - & & - Cupressus sempervirens Linn. \\
\hline
\end{tabular}

Besides these forest nurseries there are those belonging to the societies for the replanting of forests, which receive subsidies from the government.

In the forest nurseries of the government additional native plants are cultivated as well as many foreign species. This year at Vallombrosa and Camaldoli the hard, or sugar, maple, Accr saccharum Marsh, will be cultivated from seeds furnished by the Forestry Department of New York.

At Camaldoli are some of the finest forests in Europe and a large nursery that, in size and cultural methods, will compare favorably with any. In most of the forest managements abroad a preference is given to small nurseries, of two acres or less, distributed so that each will be near the place where the seedlings will be planted. But at Camaldoli and Migliano large areas have been set apart for the propagation of seedling trees, and nearly all the public forests in Italy are supplied with young plants from these nurseries.

Camaldoli is in the Apenines, Province of Tuscany, and should not be confounded with the well-known place of that name near Naples. The former is easily reached by rail from Florence to Arezzo, thence by a branch railroad to Bibbiena, and thence by a drive of fifteen miles up the mountain pass to the old monastery, which has been converted by the government into a commodious, fashionable hotel.

The nursery, or piantonaio, at this place covers about thirteen acres, and has an altitude of 2,910 feet above the sea. The ground, which has a gentle slope to the northeast, is laid out in terraces so as to afford a level situation for the beds. The exposure is favorable, as it furnishes protection from late frosts and 


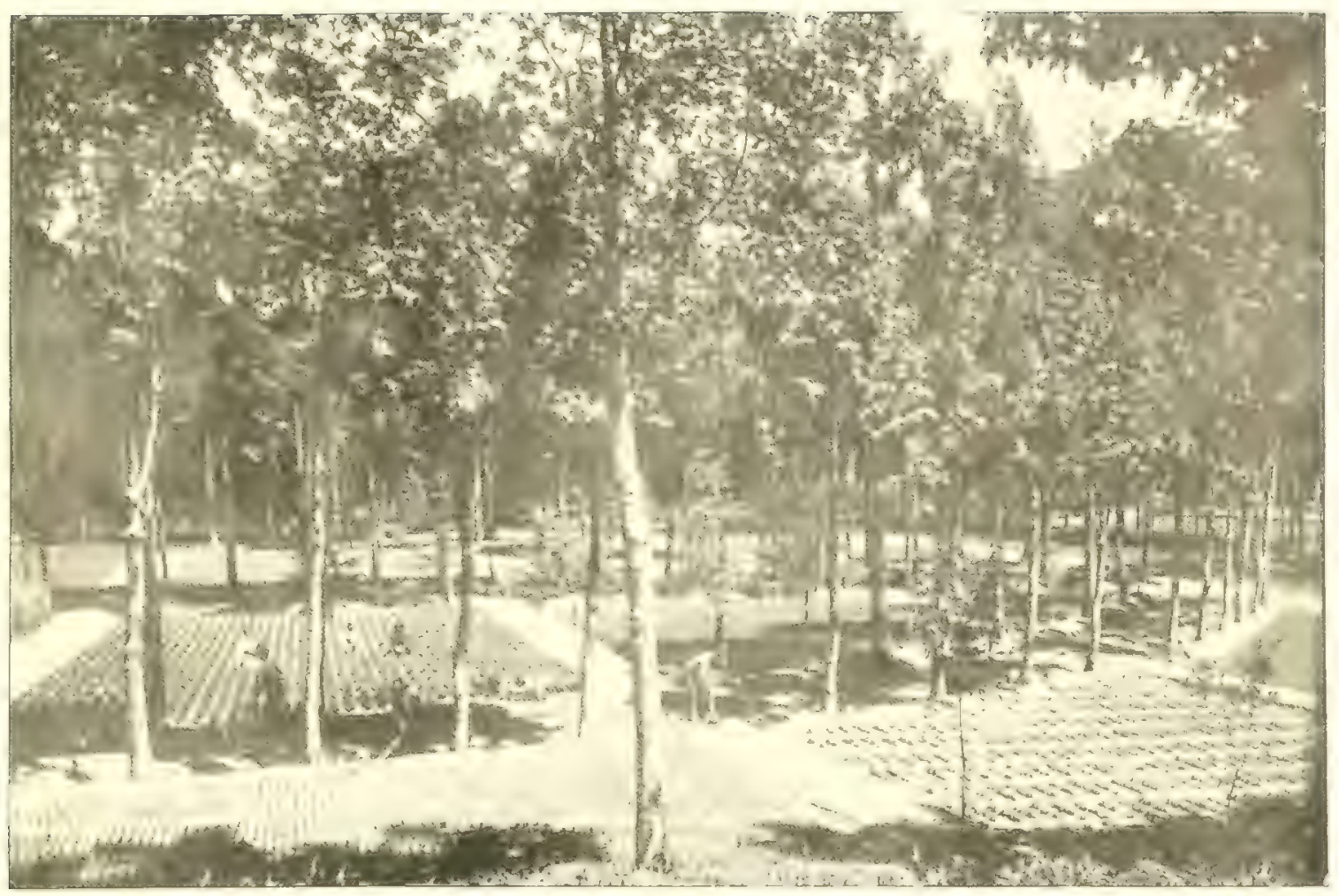

NURSEKY HEDS SHADEI BY PIANTED TREES.

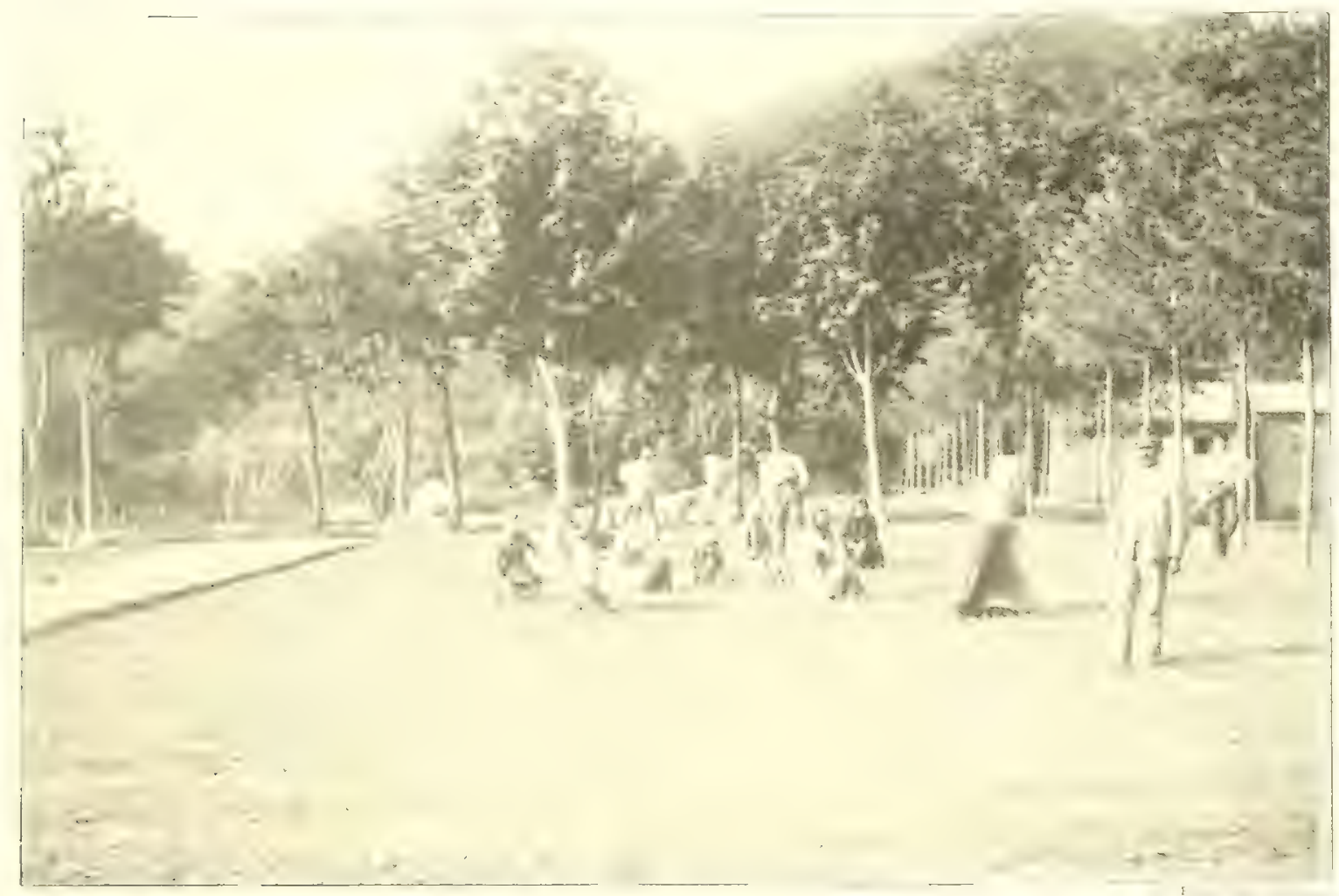

FOREST TREE NLRSERY, ITALY. 

the rapid evaporation caused by south winds. Although not closely surrounded on all sides by high forests, there is a dense tree growth near hy of rarions age classes. Owing to the altitude the natural soil is thin and porr, but the entire surface of the nursery is deeply covered with rich, friable earth composed largely of humus mixed with fertilizers. It has ihe appearance of a fine lwam, with no black earth in it aside from that brought from the forest near ly, and with enough clay and sand to give it a light color.

The beds for conifers are four feet wide, and of varions lengths to suit the terraces, most of the locls leing about thirty feet long. The greater part of the area is occupied ly transplants, the seed beds needing comparatively small space.

In preparing the seed beels the seeds are planted in rows rumning across the beds. Formerly the seeds were sown broadcast in these heds, but this mas abancloned becanse, as claimed by the forester in charge, by sowing in rows a much smaller amount of seed is used, the plants grow stronger and more even in size, are more catsily weeded, and can be taken up with less work and injury to the roots.

The seedlings are taken from the seed beds when two gears old and transplanted into the long heds, where they remain two or three years more. The transplants are then fonr or five years old, from twelve to eighteen inches high, and are ready for transter to the gromels where the final planting for the future forest is made. The Italian foresters seldom use two-ycatr-old seedlings in their fieldwork, preferring to wait for the four-year-old transplints on accome of the advantares which the latter have in size, hardiness and better root system.

The plants are allowed to remain in the secd beds and transplant beds respectively as follows:

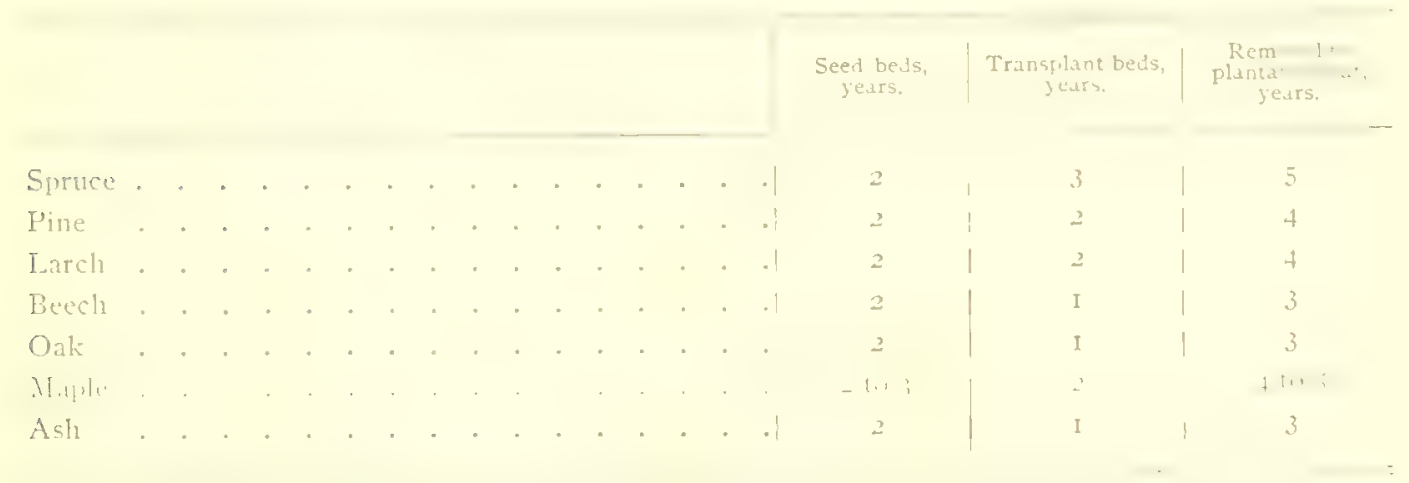

The locusts are not transplanted in the nursery, but are taken from the seed beds when they are one year old and sent directly to the final plantation in the fielst. 
The principal species growing in the Camaldoli nursery are: Silver fir, ITorway syruce, longleaf pine, stone pine, Austrian pine, larch, beech, chestnut and sy samore maple.

No lath frames are used for shade. Protection from heat and drought is obtained when necessary by using pine brush, which is stuck into the ground on the sunny side of the beds. Screens of thatched straw are also used for the same purpose. Unlike other nurseries in Europe, small trees, twenty-five feet in height, or thereabouts, are standing at intervals of twenty feet throughout the greater part of the area, and their moving shade contributes to the refreshment and protection of the tender plants. An ample supply of water for irrigation is obtained from a small, artificial lake situated on the side of a hill just above the nursery.

The beds containing the transplants are kept in fine condition, all the plants being alive and green, and at even spaces in the rows. In some of the seed beds, however, bare spots ma be seen at times, dute to the destructive work of birds and squirrels. These blanks are also liable to occur after an unusually wet season, when the excessive moisture prevents to some extent the germination of the seeds.

The management of this nursery is in charge of a forestry official who is termed in Italy a "brigadier," a title somewhat puzzling to the foresters of other conntries who may have served in the army. The work of preparing, planting and weeding the beds is done almost wholly by women at daily wages of about thirty cents each. One woman will set out about 1,200 seedlings in the transplant beds in a day, a day's work being combed as ten hours. Hence the cost of transplants is only one fourth of that in American nurseries.

Although somewhat of a digression, some mention seems pardonable here of the high forest about Camaldoli, which consists mostly of silver fir, unmixed with other woods. An hour's walk to Sacre Eremo takes one over a good road through the best of the timber, and affords an opportunity to see this famous species in a very heary stand per acre. The trees are tall, straight and of large diameter, the dense growth indicating a possible yicld of 70,000 feet, board measure, per acre, exclusive of the minor product. It was planted by the monks of Camaldoli over a century ago. Protection from fire is attained by patrols, and by watchmen posted in little cabins placed on surrounding hilltops and monntain peaks, from which they announce by sirnals the first appearance of smoke.

But on this tract, containing 3,600 acres, no cutting is seen. In x 90 I the government enacted a law that no timber should be cut in a public forest within a certain distance of any summer resort. I'erhaps the Italian legislators had react the restrictions in the forestry clanse of the State Constitution of New York and 
followed that. The proprietor of the hotel at Camaldoli semed satisfied with this cmbargo on lumbering in his immediate vicinity, and lamented the fact that on an adjoining tract of 10,000 hectares (25,000 acres) a fine forest was being cleared awa by its non-resident owner, a menuler of the Austrian nobility.

At Vallombrosa there is also a well-managed nursery belonging to the Forestry Institute at that place. It is in 'Inscany, and the forester desirous of risiting this famous resort can go by rail from Florence to San Ellero, thence by a cogwheel railway up the mountain, five miles, to saltino. From the latter place it is only a few minutes' wall to the Ilotel di Foresta and the "Istituto Forestale" at Ti:lombrosil. The nursery at this place is on the college grounds, with an altitude of 3,050 feet. The air is quite cool in summer, although the temperature may be excessively warm in the Tuscan ralleys. A high elevation is a desirable condition for a forest nursery in this latitude.

The plot contains between one and two arres, and is situated on a level terrace surrounded by groves of forest trees. It is further sheltered from wind by the mountain which, densely covered with tall firs, slopes upward from the rear of the college buildings. The beds, planted mostly with silver fir, are in fine condition and divided by well-kept paths. Through years of repeated working the earth has been converted into a composite of rich soil in which there is at large admixture of forest humus. Some of the scedlings are taken up when two years old and sent to the plantation direct, without any previous transplanting. At times a free clistribution of seedings is made to farmers or landowners who may wish to reforest their denuded lands.

The nursery at Vallombrosa has a capacity of about 800,000 pliants. In 1903 the species growing there, and the number of each, were as follows:

Silver fir

Norway spruce

400,000

European larch

30,000

Scotch pine

I 0,000

$(\because 1)-11,11)$ [.1110

45,000

in,

Austrian pone.

55,000

Beech

50,000

Chestnut

30,000

Norway maple

Sycamore maple

1,000

3, 500

L↔M-

$125, .00$

Other sperse

$15,=0$

Tut, 
Adjoining the nursery is an arboretum of several acres, mostly young trees. It contains many of our common American species, and to the forester from over the sea their familiar appearance is as welcome as the sight of old friends in a strange country. With the nursery and arboretum so close at hand, the students of the Forestry School have a fine opportunity for study and experience in this branch of silvics.

The dense forests and leafy conditions about Vallombrosa recall readily the literary quotation which has made this place so famous. The mountain slopes are thickly covered with fir and spruce, while near the college there are mixed woods of pine, locust, sycamore, mountain ash, white birch, chestnut, oak and poplar.

\section{France.}

In a country where the forests are managed mostly under the selection system and for the formation of coppice growth, as in France, the need of nurseries is consequently not so great as in one where clean cuttings are the rule. But whatever the method employed in reforesting, there is always a need for nurserygrown plants to fill the fail places. Hence there are pepintires in all the forest districts of France, some of which are absolutely perfect, not only in the technical methods employed but, also, in their attractive appearance.

One of the best, perhaps, of these may be found at Xettes, in the mountains of the French Vosges, near Gerardmer, Southeastern France. The plot is rectangular, 200 by 175 feet in size, and is inclosed by a rustic fence of neat design. It is surrounded closely on all sides by a dense, high forest of Norway spruce. The ground is nearly level, with a slight slope to the south, and has an altitude of 906 meters. The neat fence, clean paths, lons, well-kept beds and pretty summerhouse at one side well repay the long climb up the mountain from Gerardmer to find this seclucled spot. The polite and attentive forester in charge wears a distinctive uniform, as is the case in all the gurernment nurseries and forest reviers in Europe.

The entire area is devoted to the propagation of conifers-spruce and fir. To maintain the regular annual output nine seed beds are made, each about sixteen feet long, and inclosed in frames of wide boards placed on edge. These seed beds are covered with wire screens to protect them from the depredation of birds, and the screens are allowed to remain in place until August, or until the germination has advanced far enough to permit their removal.

The seedlings, when two years old, are transplanted into the long beds, where they remain two years more. The beds containing these transplants are four 


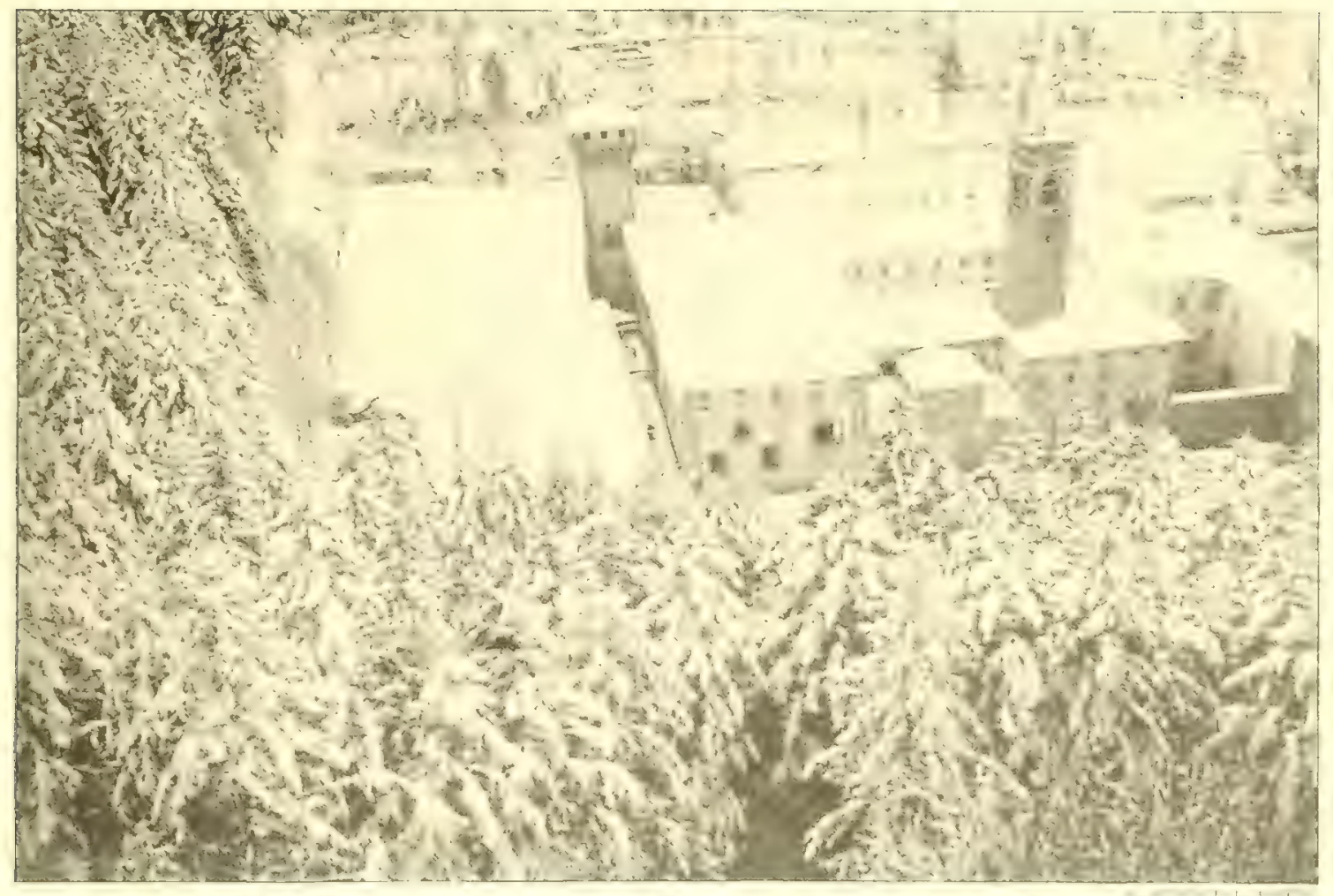

ROYAL, FORF-1k】 INSTITUTF, VALLOMBROS. I IIY

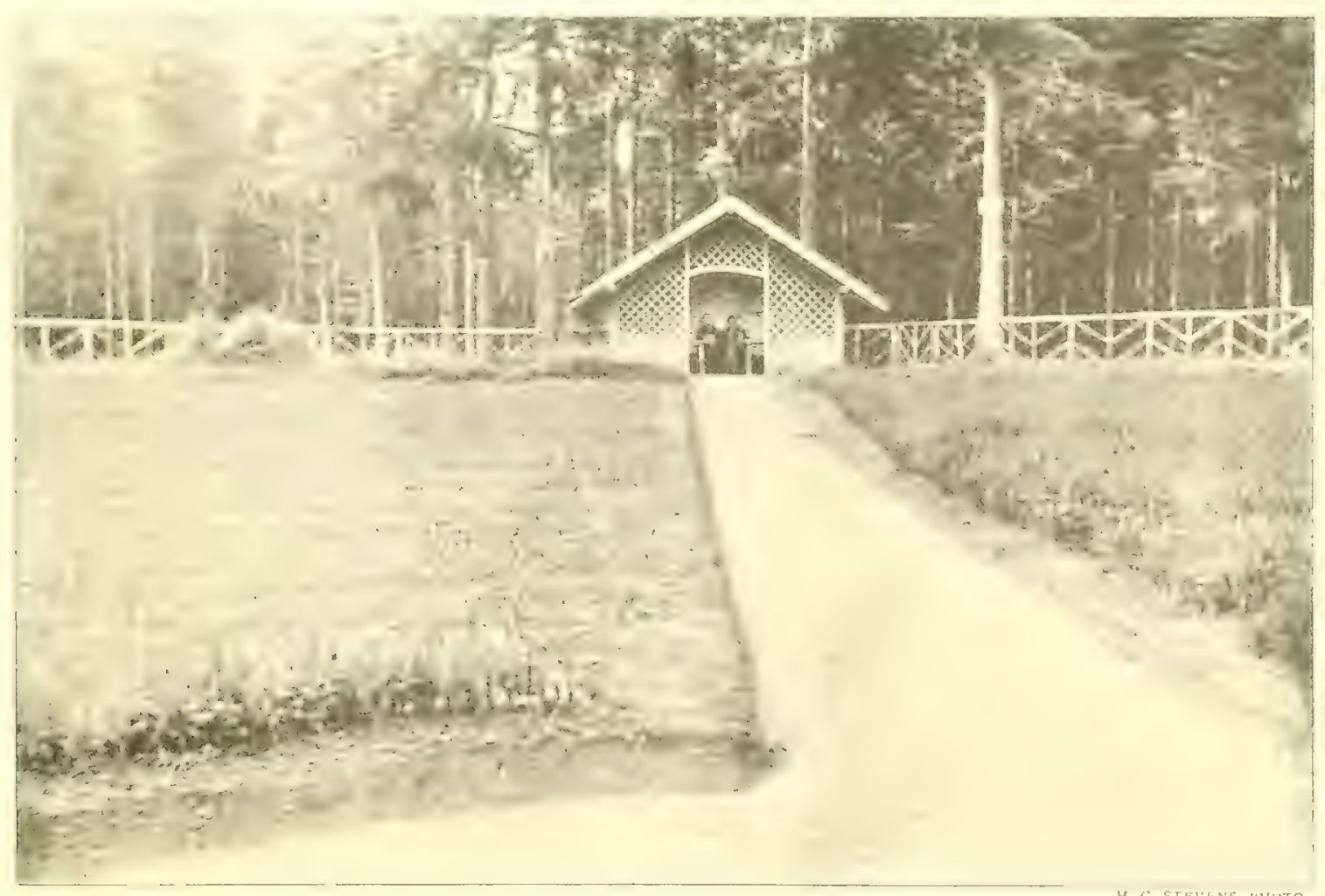

FOREST TREE NURSERY, AT IETTES. 
feet wide and extend from the central walk to the side of the inclosure. The seedlings are placed in longitudinal rows, the latter being eight inches apart. The natural soil is a rich loam, mixed with humus, to which fertilizers have been added each year after the removal of the plants. As a result the four-year-olut transplants when taken up are strong, thrifty, and from fourteen to eighteen inches in height, with a well-developed root system. (Owing to the moist climate of the French Vosges, the great altitude and the close proximity of the forest, it is but seldom that the beds require any watering.

In other districts of France many of the nurseries are used in part, and in some instances entirely, for the propagation of broad-leaved species. In the Forest of Roumare, near Rouen, there is a pefinite which is stocked wholly with heech and oak. The beech is raised in seed beds, and then transplanted the same as is done with the conifers. The surrounding forests, however, are composed almost entirely of scotch pine in pure stands. But it will be noticed throughout Northern France that, where a clean cutting occurs in a forest of the latter species, the ground is often left to reforest itself by notural dissemination.

There are several nurseries in the Forest of Intwray-Department of the Seine-which are largely occupied by conifers, and in which the coniferous beds are frequently failures, owing to the depredation of rabbits. The foresters seemed to be unable to protect their inclosures from these pests. This is not surprising, for our American nurseries suffer serious injury at times from rodents. In the winter of rgot, after a fall of snow, one of the large forest-tree nurseries in Northern Illinois suffered a loss in white pine seedlings, calused by a swarm of field mice that cut off the stems close to the wround and inflicted damages estimated at $\$ 5,000$ before their presence was discovered.

\section{Belgium.}

Although Belgium has no place on the pages of our forestry texthooks, seventeen per cent of its area is well wooded. Its forests are of a high class that indicate an intelligent, intensive management, and the extensive formation of artificial ones is provided for by numerous nurseries.

In the great Forest of Soignes, at Groenendael, there is a pipinize of two acres, in which some interesting experiments are carried on at the present time in addition to the regular work. Some germinating beds are set apart for testing the relative efficacy of various materials for covering and protecting the tender yearlings. For this purpose trials are made of straw, dead leaves, moss, dried manure, humus, plain earth pressed down around each plant and plain earth applied 
loosely. The results thus far are indeterminate, but seem to faror the use of dead leaves. Mention is made of this matter here, because each of these materials is in use in one place or another.

Other beds are devoted to experiments in deep, medium and shallow planting. Thus far the best results have been attained by a medium depth in which the root-collar was slightly covered. Experiments are also being made with reference to quick and delayed transplanting. As might be naturally expected, of the plants which were set out immediately all lived, while most of those which were delayed died sooner or later, according to the period of delay.

Interesting tests were made in trimming the roots of the two-year-old seedlings before transplanting. The thriftiest plants were obtained fiom those with uncut roots, a fact which seems to be at variance with the practice in some of the German nurseries.

Experiments were also made to ascertain the relative ability of seedlings to withstanc the effects of sun and frost. While it was found that certain species were much more susceptible to injury in this respect than others, it also appeared that none were hardy enough to enable the forester to dispense entirely with some kind of protection.

In one part of the inclosure mustard plants are used to furnish shade for the tender species growing there, while some of the beds are covered with racks on which straw and brush are placed for protection from the sun. Many of the beds which had been planted with broad-leaved species contained young trees from six to eight feet high. The coniferous transplants were not over twelve inches in height, although four years old. In general, the minor details of the technical work is the same as that described later on in connection with the German nurseries.

This nursery, which is quite irregular in outline, is nearly level, with a slight siope to the south. Labels, neatly and plainly lettered, which can be read at a glance by one standing in the paths, are placed in each bed to show the species planted there. Abont one half of the area is occupied by broad-leaved plants, conspicuous amongr which are ash, beech, European chestnut and oak, the latter including the red, scarlet, English and pedunculate. This place is well worth visiting by any forester who may happen to be in its vicinity.

Adjoining the nursery, and separated by a fence, is an arboretum which was commenced in $1 S_{97}$, and hence the trees are small. But it already contains three hundred and twenty-one species, among which our native American trees are largely represented. 


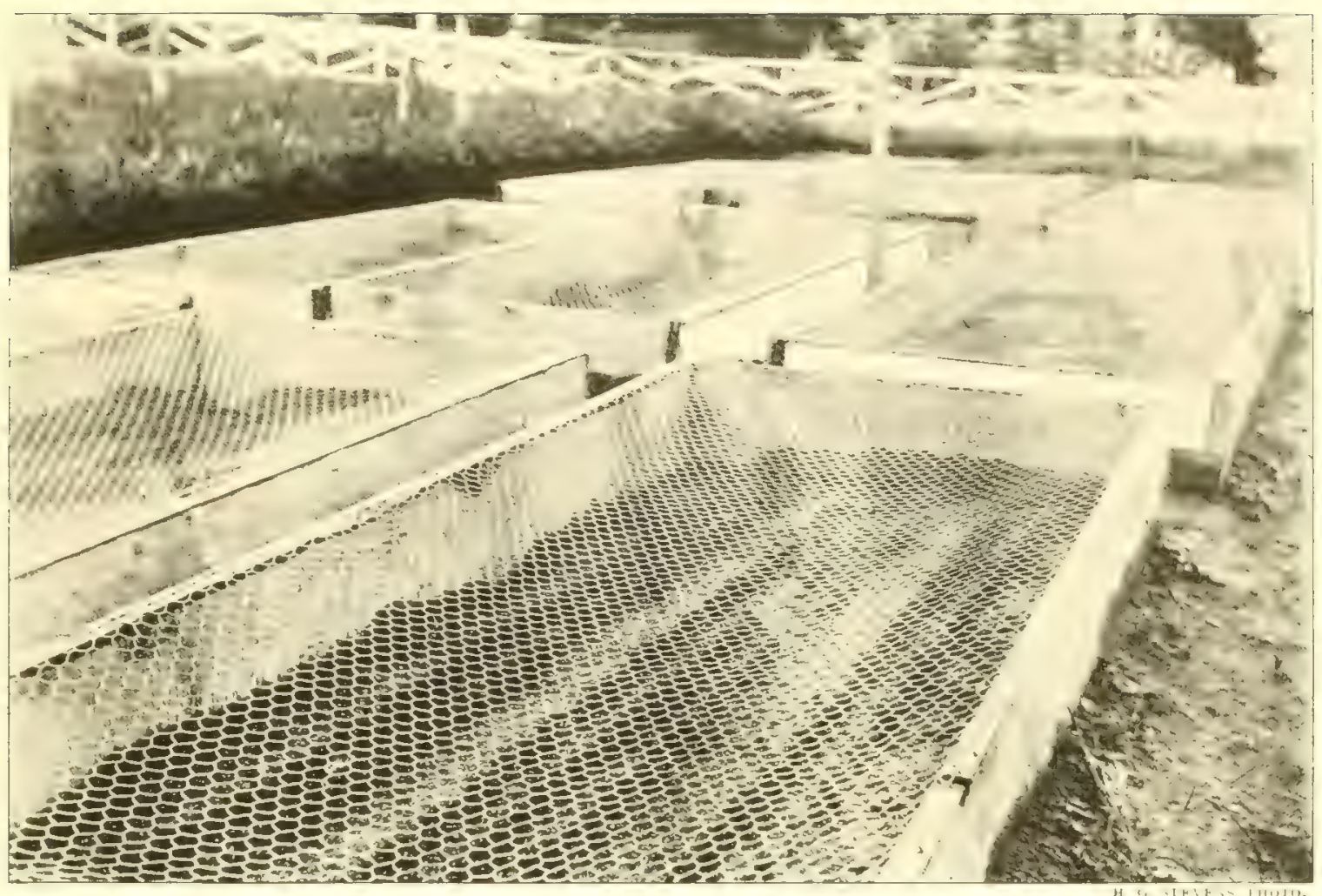

FOREST TREF NURSERY, NEAR GERARDMER, FRANCE.

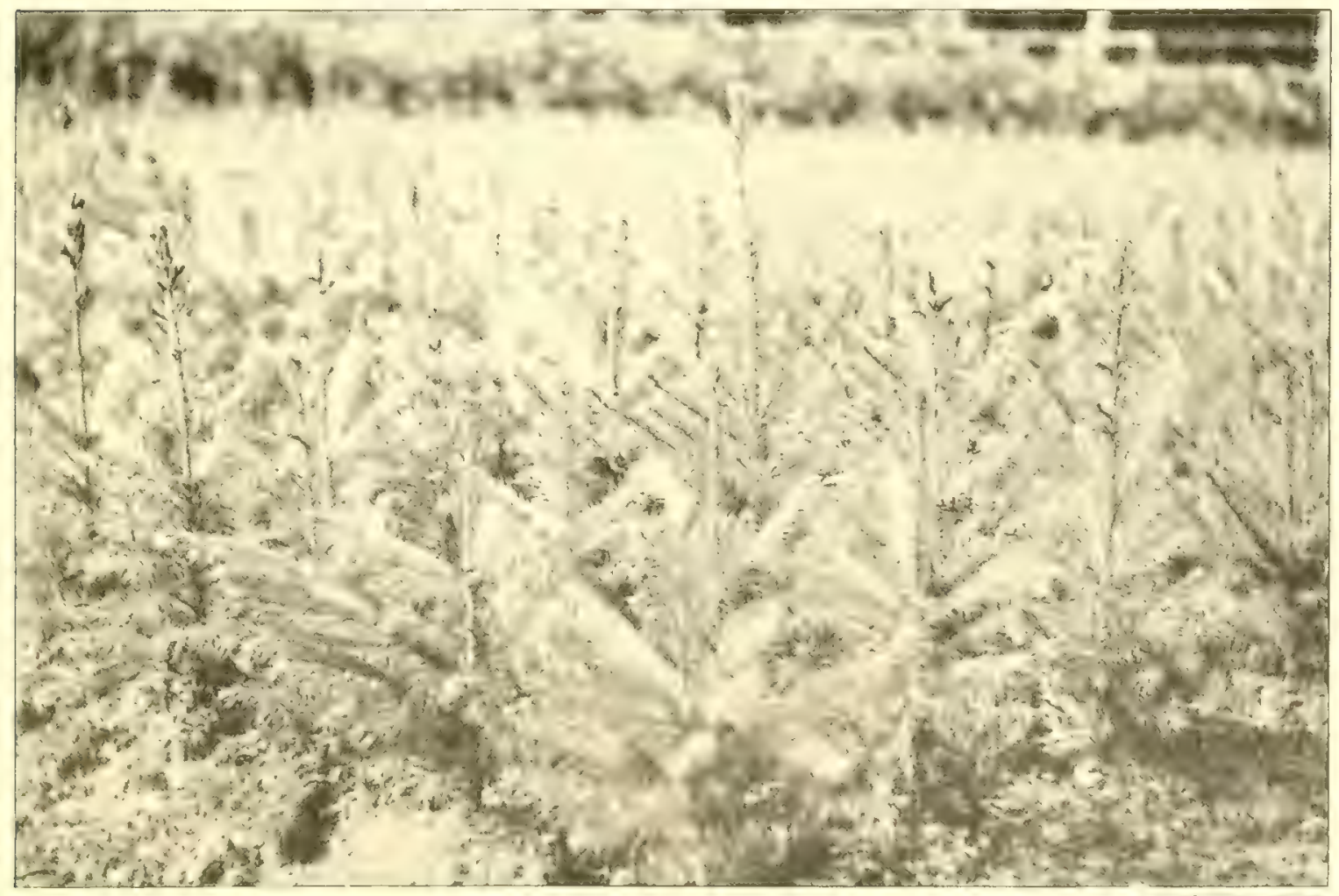





\section{rjaden.}

The extensive areas of planted woods in the Black Forest require a large number of nurseries for carrying on the work and for renewing the prowth on lands as fast as the timber is remored. The well-manitged banmschule at Geioldsau, near Faden-Baden, is a far type of the small but numerous nurseries that may be found in the various clistricts of the Schwarzmald.

It has a square area of about half an acre, is Jocated in a valley rumning east and west, and is situated about one handred feet above the bottom of this valley on the southern slope. The forest approaches closely on three sides, while the precipitous slope on the opposite side of the ralley is also well covered with tree growth. 'The nursery is surrouncled by a paling fence, and a good road, used mostly for hauling timber, skirts the lower side of the inclosure.

The area contains one hundred and sixty-eight beds, ench fifteen feet long and forty inches wide, separated by paths of convenient width. Two broad paths, four feet wide, one running through the midlle up the slope and one at right angles to it, divide it into four equal parts. The main paths which separate the beds, and which run up the slope, are three feet wide, while the crospaths at the ends of the beds are twelve inches wide.

The earth in the beds is a rich, sandy loam, prepared by mixing one load of ordinary forest soil with one of manure. This compost, until used, is piled just outside the fence, where it is allowed to remain undisturbed for three years. Three large heaps are necessarily lept on hand to furnish the proper annual supply.

The seed beds, eight in number, occupy only five per cent of the total area. These beds have a framework of boards around their edges, eight inches high, and are covered with wire screens of a small mesh, which are kept there until the seeds have germinated to protect them from the depredation of birds. The seeds are sown thickly and hroadicast instead of in rows.

If the supply of plants from the seeci beds is insufficient to stock the area set apart for transplants, the deficiency is made up by gathering two-year-old seedlings from the adjacent forest.

In 1903 the species growing in this nursery were:

(I) Weisstanne, or silver fir, three and four years old.

(2) Rottanne, or Norway spruce, four years old.

(3) Sitka spruce (Abies sitchensis), three years old.

(4) Forle, or Scotch pine, four years old.

(5) Douglas spruce, four years old. 
In addition there were, in a few beds which contained an assortment of species, some larch, sycamore, maple, Colorado spruce, white fir (Abies concolor) and Larix leptolcpis.

The seedlings, as customary in most nurseries, are allowed to remain in the seed beds until they are two years old, when they are transplanted into other beds in the same nursery. These transplants are set out lengthwise of the beds in eight rows, fifty in each row, four inches apart in the row, and with a space of about six inches between the rows. This is closer than usual, but the forester claims that if the rows of transplants are set too far apart there is a tendency to fork, to the formation of two leaders, which, by the way, is one of the disadvantages urged by some against a plantation formed of nursery stock.

In transplanting a furrow is first made with a "hand-plough," which is drawn by one man and guided by another. Then a board with notches cut in the edge at distances corresponding to the spaces between the plants is placed on the bed with the notches over the furrow. The seedlings are then placed, one in each notch, the roots covered with prepared soil, and pressed into place. In some nurseries a planting board* is used which has half circles along the edge at the required spaces instead of $\mathrm{V}^{\top}$-shaped notches.

The longer roots of each seeding in the Geroldsau Nursery are clipped slightly to insure a greater amount of branching and a better root system in the transplants. This is deemed desirable by the forester, as it saves the expense of making a deeper hole when the final planting is made in the forest, and because there is less liability to loss in transplanting.

The transplants of the Weisstanne remain from three to four years in the beds, mostly four years, while the Rottanne are held in the transplant beds from two to three years, the length of time in each case depending on the height-growth attained. For the Rottanne a height of about twelve mches is deemed desirable in the transplant before removing it from the bed and taking it to the forest for final planting; but the Weisstanne, which is slower in growth, is removed from the nursery when eight or ten inches high.

At the corners and sides of each bed there are posts, about three feet high, which support long poles placed horizontally on top of the posts. If the post has no natural crotch in which the poles can rest, a hole is bored near the top of the stake and a round stick is inserted to furnish a bearing. From the first to the

* In New York we use this kind of board in our nursery work, but we set out our transplants here in rows running across the bed, which enables us to use a shorter board and to make the furrows by hand with a trowel pressed deeply into the soft earth. Furthermore, with rows placed this way a man sitting in the path can do the weeding more easily. Still, each way has its advantages, and, some disadvantages also. 


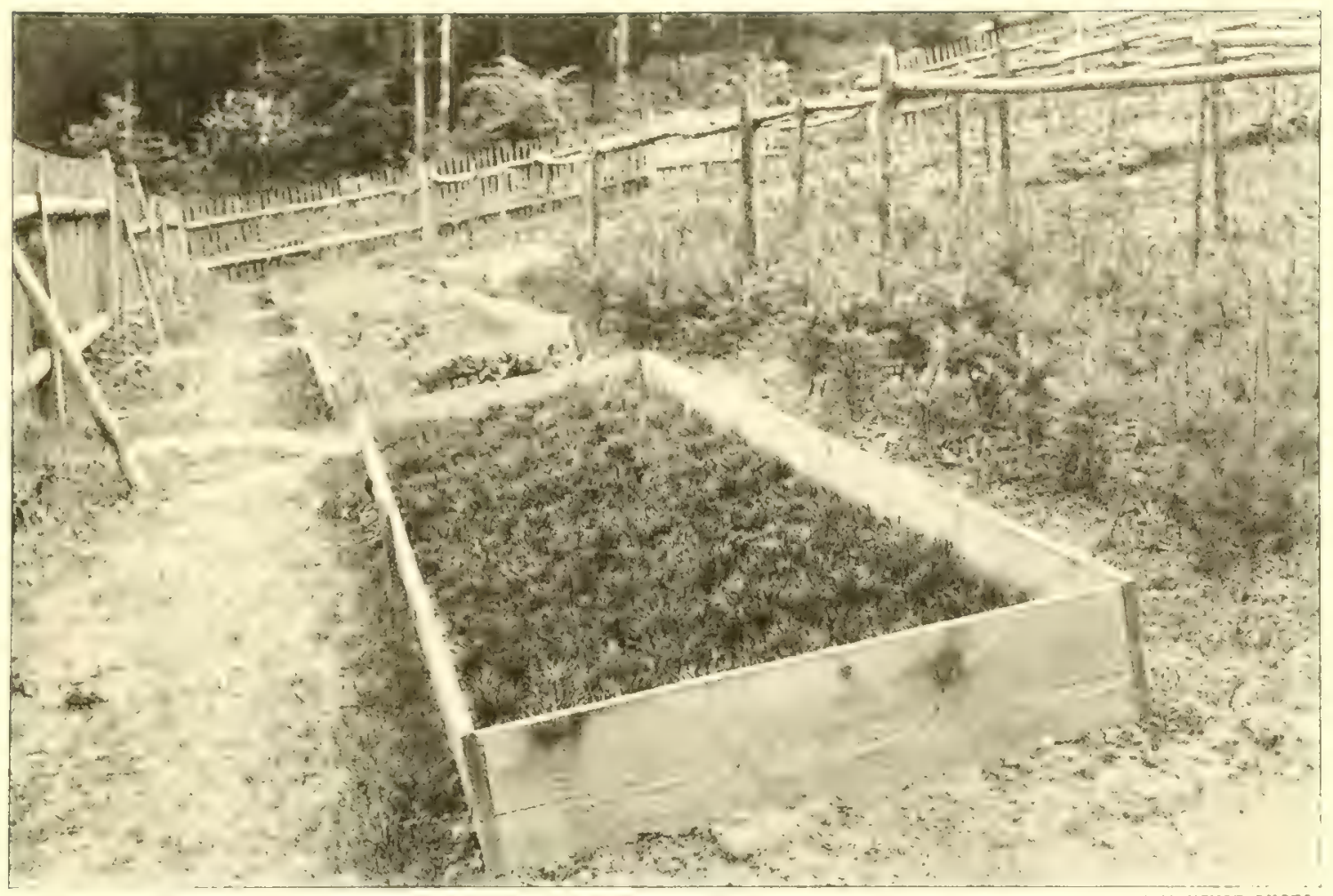

SEED BFD OF SCOTCH PINE, TWO YEARS OLD.

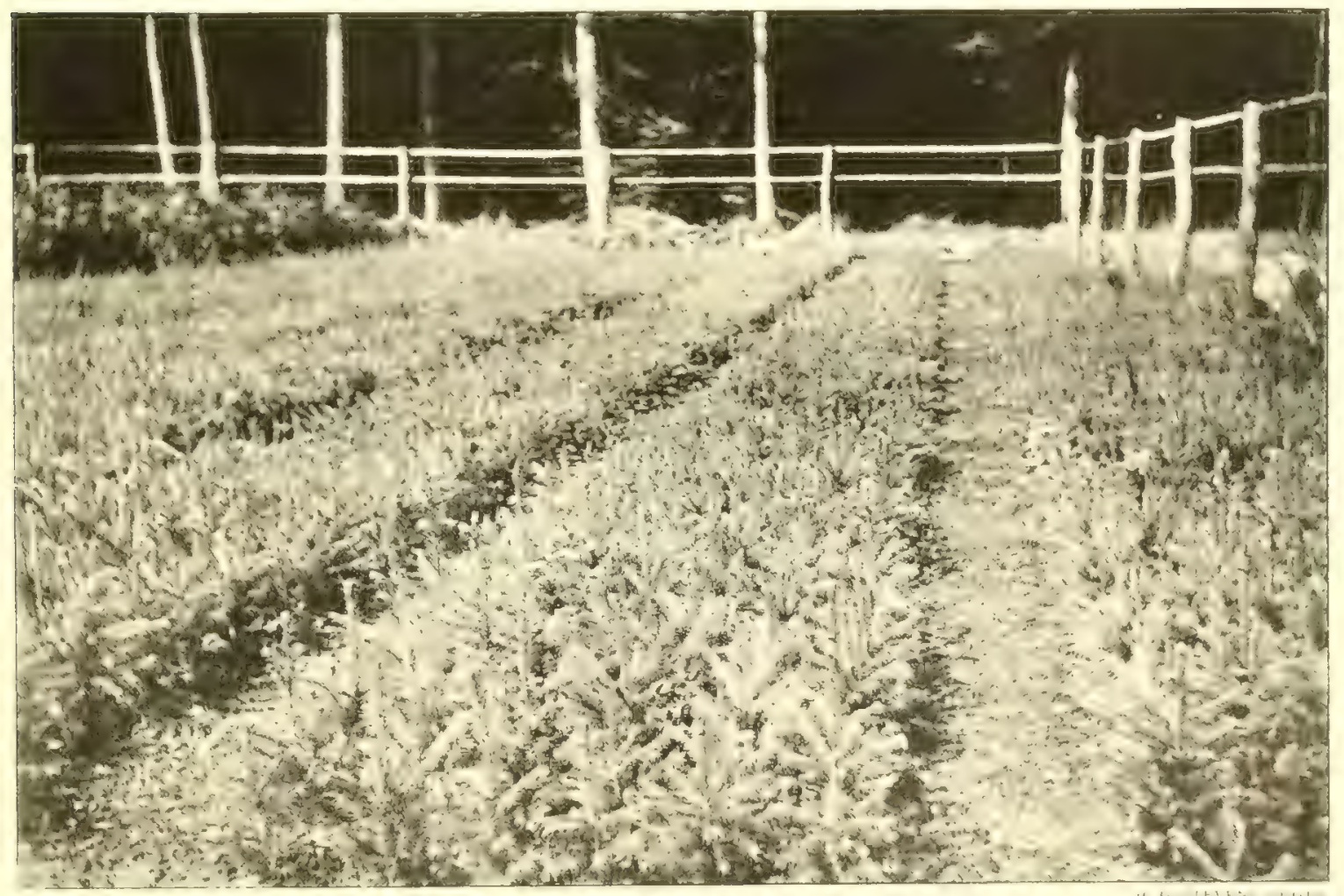

IEEDS OF FOUR-IEAR-OID TRANSPLANTS, NORWAY SPRUCE. 

twentieth of May these horizontal poles are covered with brush to protect the transplants from the frost which is liable to occur in the valley.

The total number of transplants in this nursery, in 1903, was 65,000 , of which I7,000 six-year-old Treisstanne were to be set out in plantations the following year. The Weisstanne formed the principal species raised in this plot, comprising ninety per cent of the plants. The Rottanne, or Norway spruce, occupied only five beds, or about three per cent of the aren. There were also a bed of Sitka spruce, one of Douglas fir and one of Scotch pine. But there is another nursery in this revier, under the same fürstmeister, in which the plants are nearly all Rottanne.

The cost of the plants, when placed in their final position in the forest, is from $=$ to 4 pfennig (one half to one cent) per plant, a laborer being able to set out from $\mathrm{I}, 000$ to $\mathrm{r}, 200 \mathrm{in}$ a day. In setting out these plants in the field he uses a kind of mattock for making the holes, the same as is used in onr plantations in New Iork. The daily wage of a laborer in this range is I mark So pfennigs, and hence the cost of annual planting in the forest, at the rate of $I$, Ioo plants per day, is r.6 pfennigs per plant, which leaves the aiplorent cost of the nursery work from of to 2.4 pfennig per plant, not including certain incidental expenses, which increace it somewhat. *

There are six nurseries in the Bacien Revier, eatch about the size of the one at Geroldsau; but they rary greatly in the species propagated, some of them having ninety to ninety-five per cent of their area devoted to Norway spruce. The broad-leaved species are cultivated only to a small extent in this part of the schwarz⿻ ห1,

The nursery in the Wendlingen Revier, near Freiburg, is also devoted largely to the propagation of the silver fir. It is a permanent one, so denoted to distinguish it from the temporary ones often made to supply a local need. The natural soil is from meneiss, and is a limy sand. Minure is used as a fertilizer, that from cors being preferred. This is spread over the ground and spaded under before the seed is som. Thomasmehl and kaint also are nsed.

The seeds in the seed leels are sown in rows, the rows being three inches apart, and are droppea so thickly in the row that they nearly touch each other. The buels are then corered with branches of fir or beech, which are allowed to remain all summer, at first close to the ground, after which they are raised Eradually until they are about twenty inches high. These shades are also left on through the winter to keep the wround from freezing and heaving with the frost. Moss, or fine brush, haid between the rows might serve this purpose as well.

* These figures scen sumewhat inestionalie, but they were noted down carefully from the forester's personal statcment. 
The seedlings are transplanted, when two years old, in rows six inches apart and at spaces in the row of about three and one half inches. They are held in the transplant beds until they are five years old before removing them to the plantations.

Although the purchase of seeds for nursery purposes is a common practice in some localities, the forester in charge of this revier gathers his own supply. As to the silver fir, a full mast occurs about every five years, although this species yields a small amount of seed each year. The cones are gathered about the midcle of October. A man climbs up among the branches and breaks off the cones, which are carried immediately to the storehouse and spread out so that the air can circulate through them freely. They are stirred every day and kept in the drying-room until the scales have fully opened or fallen apart. They are then put into baskets and shaken vigorously until the seeds have fallen to the bottom, after which they are easily separated from the refuse material.

The seed beds are sown in autumn, sometimes in November or December, if snow does not fall ton early. If the weather is very moist the cones may not open in time for fall planting. In that case the seed is, of course, sown the next spring.

The absence of nurseries in some parts of the Black Forest, or elsewhere, does not necessarily imply that young plants are not tused there in reforesting operations. In the Sulzburg reviers, for instance, the oberförster, as explained by him, is doing very little in the way of seed plots, because he can buy seedlings from the commercial nurseries as cheaply as, if not cheaper than, he can raise them himself. This is not remarkable, as it is evident that in a nursery of one hundred acres or more, devoted solely to commercial purposes, the plants can be raised more cheaply, and with a profit, than in one of two acres, especially as in the latter case the forester has other and more important duties that engross his attention. Furthermore, under the excellent and intensive management of the Sulzburg reviers a satisfactory reproduction is obtained through natural dissemination.

\section{Sivitzerland.}

As most of the forests in this country occupy slopes, more or less steep, they exercise protective functions which necessitate the selection system in their exploitation, and hence there is not the same need for nurseries as in countries where clean cutting is practiced. Reproduction by natural dissemination is largely the rule, noticeably so in the forest of the Sihlwald, famous for its intensive management and the highly profitable returns per acre which have been main- 


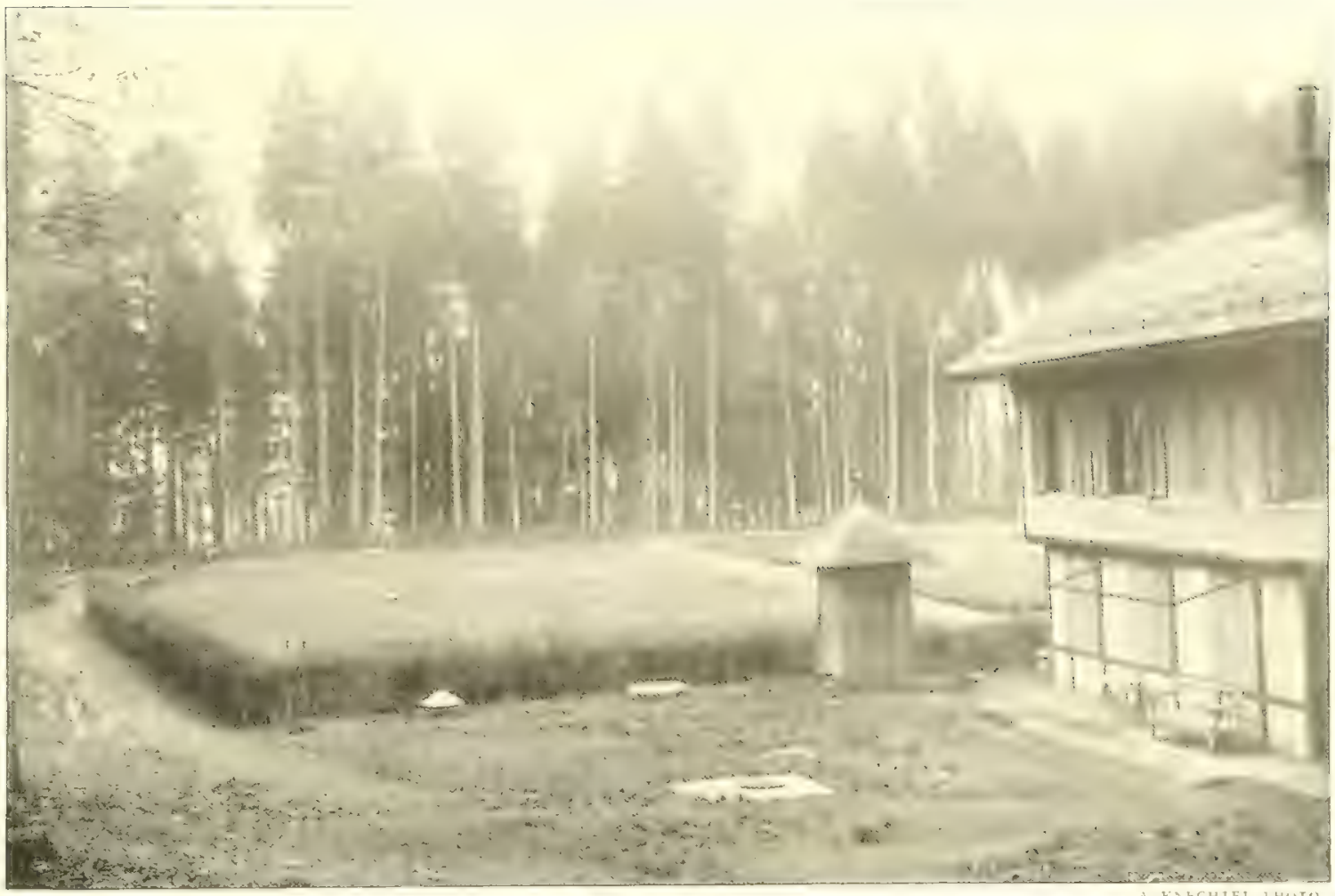

FOREST TREF NURSERI, NEAR IUZERNE, SIVTTERLAND.

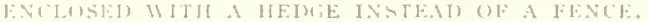

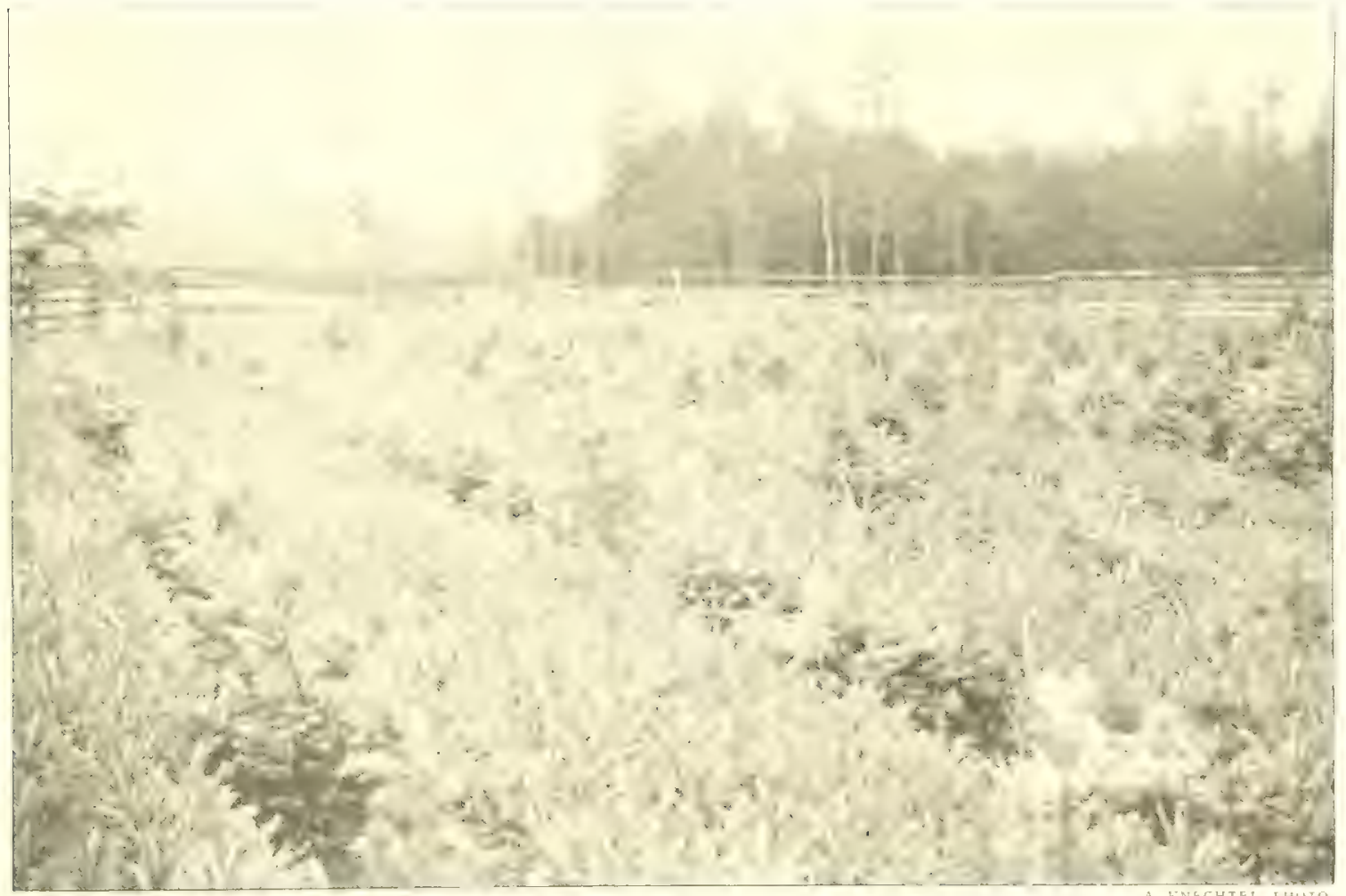

TIMIORARI NURSERY.

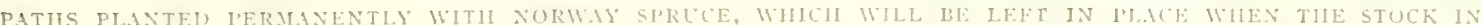
THE EEIS IS JINALLY REMOVFI, A PLANTATION THUS TAKES THE, ILACE (IF TIIE NIKSERY, 

tained annully for a long term of years. Still there are several nurseries connected with the management of the various cantonal forests, but the technique as observed does not vary materially from that already described.

Although nurseries are not as essential to the management of high forests in Switzerland as elsewhere, a large number are uscd in the work of forest extension and the formation of new forests on wild or cultirated land that had hitherto not been used for the production of timber. From 1878 to 1885 the annual output of the nurseries deroted to this purpose amounted, on an arerage, to $5,26.374$ conifers and $35 \mathrm{~s},+30$ broal-leaved plants. *

In the Winterthur fange temporary nurseries are used to a considerable extent. In some of these, when the stock is removed, a sufficient number of transplants are left standing at proper intervals in the beds to form an artificial forest in time on the site of the abandoned nursery plot. 'The permanent nurseries wherever seen are in admirable condition and have an attractive appearance. One of them, near Luzerne, is enciused by a well-kept hedge instead of a fence, as customary everyhere else, and is equipped with water pipes and several hydrants for sprinkling the beds.

In the canton of Zurich there is a nusery connected with the Forest Research Station, in which experiments are carried on with different species of forest-tree seedings and plants. It is situated at Adlisbers, four miles from the city of Zurich, at an clevation of two thousand three hundrod feet above the sea.

To determine the species suitable for planting in various parts of Switzerland, soils from these places are brought to the nursery, seerls are planted, and the little trees as they grow are studied and their development carefully recorded.

An important experiment is being carried on with the seed of Norwa spruce. Guod seed collected in the mountains, some from trees growing at an altitude of onc thousand five lmndred feet above sea level, and some from similar trees at in altitude of six thonsand feet, were planted in a bed in the nursery, half of the bed being given to each kind of seed. 'The seedlings, now six years old, show a remarkable difference in height, those from the seed taken at the lower altitude being twenty-four inches tall, while those from the higher altitude have a heiglit of only twelve inches.

The natural laws under which the roots of trees are developed are being studied as follows: Boxes thirty inches high, eighteen inches wide and six inches through, with the sides made of glass, are filled with earth and sunk into the ground their full length, the glass sides standing vertically in close contact with the earth outside the box. In each box is planted atree, which, as it grows, sends some of

*U. S. Consular Reports. I887. 
its roots against the glass sides. From time to time the boxes are pulled out of the ground and the root growths observed and recorded.

Observations upon white pine, Scotch pine, silver fir, beech, oak, birch and maple have been carried on for three years on plants aged from one to six years. During the winter, from November till March or April, the roots of the needle trees, as observed in the boxes, make no growth. Those of deciduous trees, on the contrary, do not go through this period with complete rest, but grow wher. ever the temperature becomes mild, even in midwinter. In February and the beginning of March, however, the roots show very little growth.

It is noticed that in the spring the roots begin to develop before the buds, in some cases several weeks. The larcin and alder are an exception to this rule. The buds of these species have been observed to unfold even a month before the roots started.

Since the soil has a temperature below that of the lower air it follows that the roots begin their growth at temperatures lower than that necessary for the development of the aërial parts. The minimum temperature necessary for the growth of needle trees, as recorded by a thermometer placed in the boxes, is from five to six degrees Centigrade; for the maple and beech, from two to three degrees.

The roots have also a summer rest, in August and September, a time when the water content of the soil in the numsery is at its minimum. This interruption may last from three to eight weeks, according as the summer is wet or dry. Then follows in October a period of more active growth and of longer duration in the deciduons trees than in the conifers.

The most rapicl development takes place at the beginning of summer. The oak has its maximum at the end of June or the beginning of July. The root growt is then about 3.5.t inches a day, that of the fir and Scotch pine about 2.36 inches. From these obserrations a judgment is formed as to the most favorable time to plant trees in the forest. For the success of a plantation it is essential that, as sonn as the trees are placed, the rows should enter upon a period of active srowth to replace the water taken from the tree by evaporation. On the other hand, the plantation should be made when transpiration is at its minimum. These conditions are usually best secured in the spring. In a country, however, where the spring is usually dry and the fall mild and moist, the plantation should be mate in the autumn.

For deciduons trees to grow well when planted in alatum they must form root hairs before the arrival of the great cold, and must lose very little water by craporation during the winter. Hence, in countries where the winter is very cold and dry these, as well as the conifers, should be planted in the spring. 


\section{Xlsace.}

The Oberförsterei Minnster, in the (ierman Vogges, has an area of 21,325 acres, of which one half, or thereabouts, is occupied by silver fir * the remainder by Norway spruce, Scotch gine (r,500 ances), beech (mixed with matle), elin and carpinus (5,000 acres), wak ( 1,150 acres), chestunt (iso acres) and locust.

The total numsery area for the tract is foul acres, which furnish an average ammal output of 160,000 coniferous plants. This nursery area is in severul small plots distributed conveniently throughout the tract. One of these, focated about five miles from Metzeral, has an area of five ares $(5.380$ square feet). It is in the forest and is closely surrounded by trees. A wire fence of four strants, with at round top-rail of poles, protects it from deer. The exponture is towath the wert. It has a slope of one fout in eight, terraced with retaining walls of stone three feet high.

The suil is from aneiss, with some line in its comprosition. Thomasmehl and kainit are used as fertilizers; † but as kinit is strong and liable to injures the plants

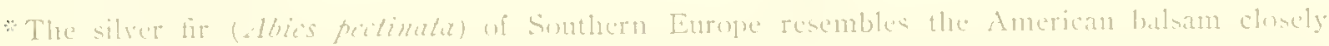

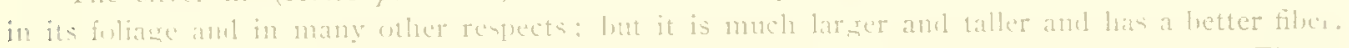

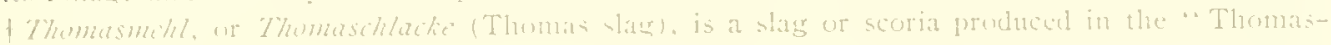

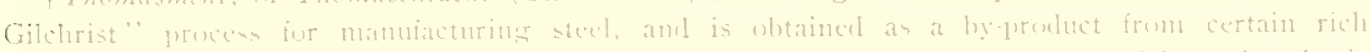

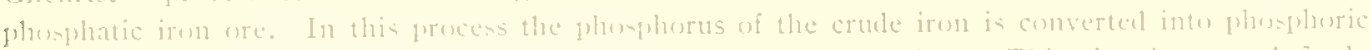

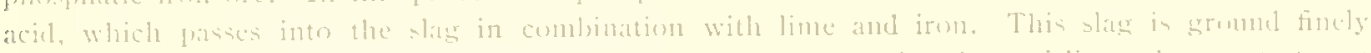
and ond as fertilizer. It contains from thiry to forty per cent phosphat of lime, the greateat part

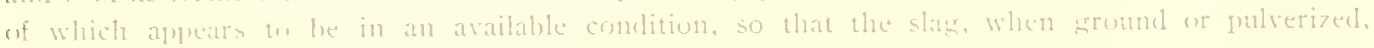

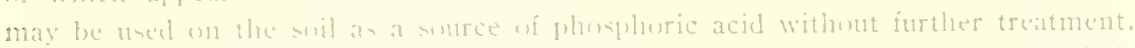

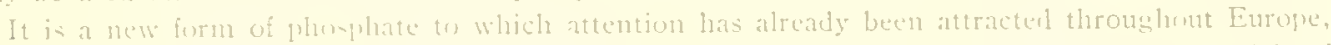

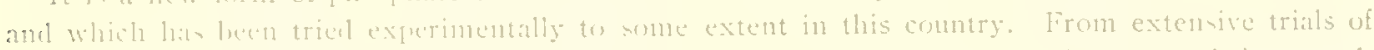
it at experiment statiuns it scems that all such slags liave not an equal value, some being much more avalable we the flants than whers. The better clames of slag have, howerer, given better remilts than bume meal, and have been sold at so low a rate the foresters can use it profitably. This sher meal in now manufactured at I'ottstown, Pa., and is put on the market moler the name of "'xlorlus [phosplate."

Finimit, of Kilditurgum, is a product of some salt mines, motably the mines at Stassiurt, Germany. It is a mixture of componnds containing about twenty-five per cent sulphate of potash, equivalent to twelve per cent of actual putash, together with about thirty-five per cent of common salt, some sulphate and chloriele of masnesia. and a small amount of grysum. Large amounts are anmually expurted to America, one year as high as 87,035 tuns.

Kainit, sprinkled on manure, tends to the checking of fermentation; also, to attract and hold moisture. One precaution should be observed in the use of this fertilizer: animals should b: lept away from it, as their feet nuy be injured by trealing in it. It is better, therefore, to apply it mixed with fresh manure, and to cover the ground afterwards with some kind of litter. [Sece bulletins on "Commercial Fertilizers," issued by the Departments of Agriculture in various States. For further definitions of Thomasnehl and Kainit, see Illustriertes Forst und Jagel Lexikon, by Dr. Hermann von Furst. Berlin: Patıl Parey. rgo4.] 
if applied when fresh, kali salts are used at times. This is a product of the German mines, containing about fifty per cent sulphate of potash and thirty-five per cent sulphate of magnesia.

Silver fir and Norway spruce are the species cultivated for the most part. These are transplanted when two years old, and allowed to remain until they are four or five years old before they are taken to a plantation.

In winter, to prevent the plants from heaving out by frost, they are covered with leaves from deciduous trees. Twigs of fir are stuck into the beds at close intervals, so that the wind will not disturb the leaf covering.

\section{Saxony.}

In no European country have improved forestry methods attained a higher development and degree of efficiency than in Saxony. In the United States consular reports it is stated that there is probably no country in the world where higher revenues from the forests are obtained, nor where greater or more intelligent care is bestowed upon them, and the forestry publications, official or otherwise, issued in that country indicate that this statement is well founded. Forests of wide extent exist everywhere, not only on the Erzgebirge and on the mountains of the Saxon Switzerland, but also in the vicinity of the principal cities.

The area devoted to the formation of coniferous forests is six times that given to the growtl of deciduous species. Gen. C. C. Andrews," in his "Notes on European Forestry," says of the Saxon forests: "The entire area planted annually varies according to circumstances. On the average it will reach 6,900 acres. Of this aren Soo acres are planted up with seeds, and 6, roo acres are planted up with plants." This statement will give some idea of the large number of nurseries in Saxony which are necessary in making such extensive plantations.

On the Olbernhau Revier, in the Erzgebirge, there are several nurseries. This revier contains $4,60+$ acres, of which four fifths is covered with Norway spruce. The nurseries are temporary ones (saatschule unstindige), small plots situated convenient to the areas in which the plants are to be set out.

The soil is good, consisting of disintegrated gneiss with considerable lime. For the temporary nurseries, small areas only are used. When a new place is selected for a "saatkamp," as the plot is called, the ground is not fertilized at first; but if it is used for a second crop the ground receives an addition of Thomas slag or kainit. Potash (kali) is sometimes applied instead of kainit, as the latter is too strong, and if used when fresh it injures the plants at times.

* Nintl Annual Report, Minnesota Forest Commission. St. Paul. Igo.4. 


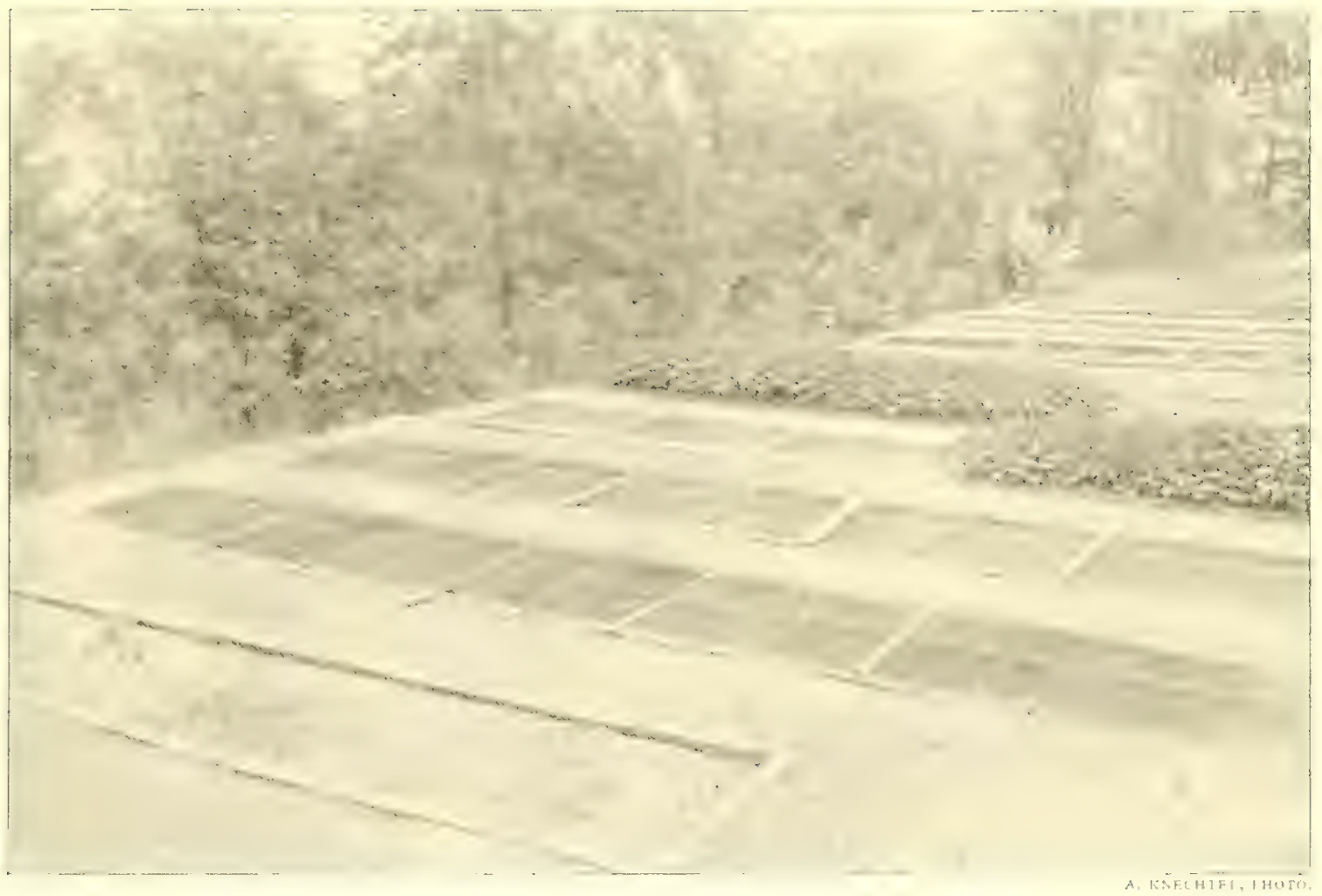

NURSERY WITH SEED IBEDS PROTECTED FROM IIIRTS AND MICE BY IVIRE SCREFNS AND STONE BORDERS.

AT ULHERNIIAL, IN THE GRACLHIRGE, SAXUNL,

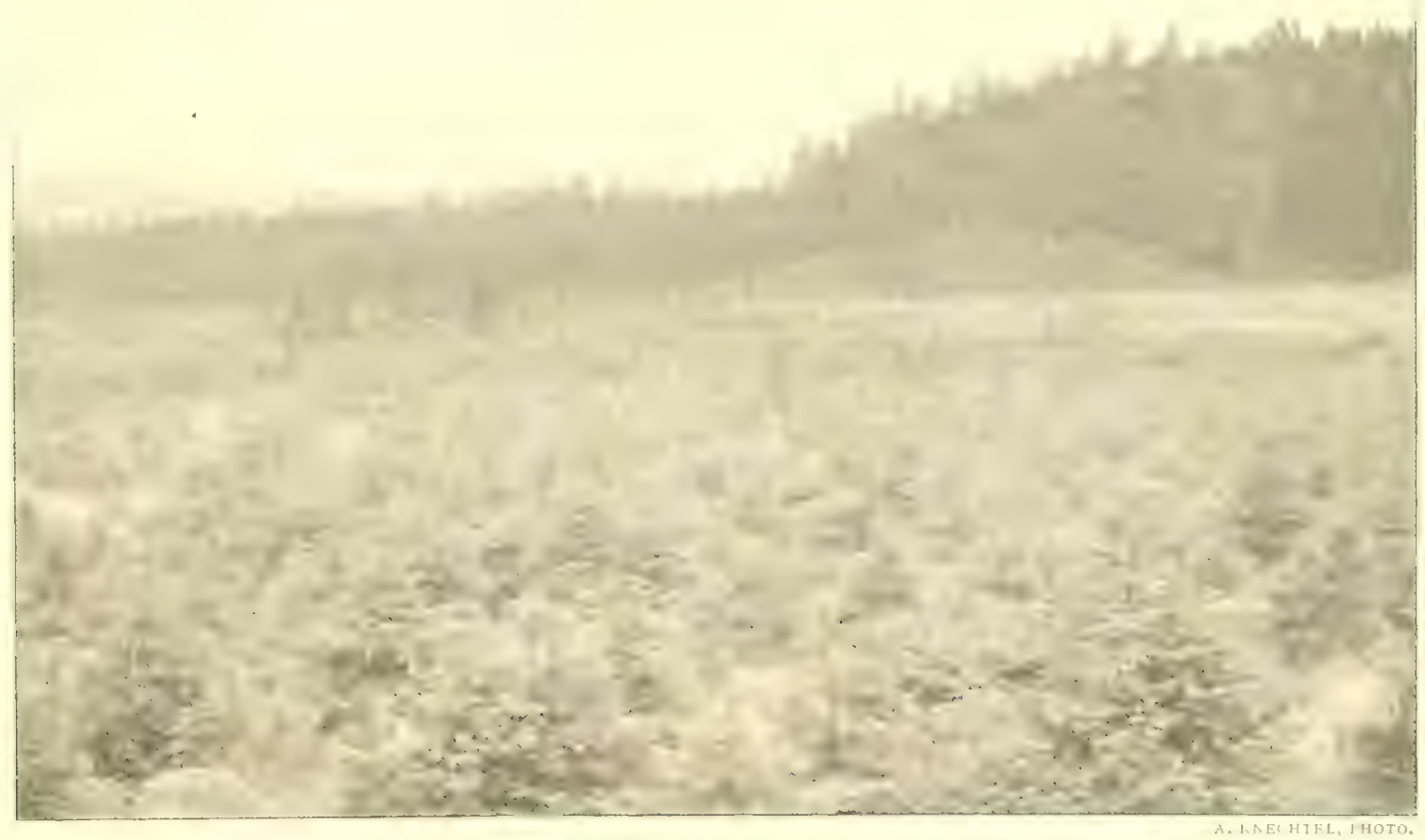

YOUNG PLANTATION (IF ANORWAY SPIRLCE MADE IB' THIE SEED-SIOT METHOD. 

These furtizers are applied immediately after the plants are removed from the nursery, which is generally done in April. They are mixed with the soil, after which the ground is left undisturbed for two weeks. 'The beds are then made and the seed is sown in them. Where the nitrogen in the soil has been lost through washing and leaching, lupine is sown in the spring and left to grow until September, when it is spated unter.

'he seedis in each row are placed thickly, nearly' touching each other, in a depression made by a square-edged slit two and one quarter inches wide. The depression thus made is about three quarters of an inch in depth. The rows are abnut four inches apart. The beds are forty inches (one meter) wide, with intervening paths of one foot in widh. For sowing an area of one are ( $x, 076$ square feet) about seventeen and one half pounds of spruce seed is used. The seeds are not soaked, lut are conted with red lead to prevent the birds from eating them. After sowing, the seeds are covered lightly with sand which has been mixed with a compost mate from leaves and grass.

The beds are covered with low screens of brush, preferably pine, which are left on the frame until the latter part of July. Water is not used for sprinkling unless there is a supply conveniently at hand.

Seedlings are left in the seed beds until they are two years old, when, as a general rule, they are transplanted into other heds; but sometimes they are left in the germinating beds until they are four years old, in which case they are sent direct to the field plantation. The clinute in the Erzgebirge, however, is so unfarorable that the foresters deem it advisable, in general practice, to use transplants.

The expense of raising two-year-old seedlings in the Olbernhau Revier is from one to two marks per thousand plants; to prepare the soil and transplant them costs one and one half marlss more per thousand; and to set them out in a plantation, from ten to fifteen marks per thousand.

Field planting loy the seed-spot method, a modified form of nursery work, is cxiensively practiced in saxony, and plantations of this kind are made at Thament the seat of the Royal Forest Academy. The Saxon foresters generally sow the seeds along the edge of the strip or patch, where they are not so liable to be heared or thrown out by frost. In the Erzgebirge, wherever this methox is used, spruce is not mixed with pine or larch as at Tharandt. At the latter place a mixture is used to protect the spruce from the deer. A few seeds of pine and larch are mixed with the spruce seed, and as the former have a more rapid growth, and are prefered by the deer, the spruce remains uninjured. 
At the Oberwiesenthal Revier, in the Erzgebirge, along the Austrian border, the technical work in the nurseries is about the same as that just described.

The nurseries are devoted almost exclusively to the propagation of Norway spruce. The soil for the most part is of a kind known there as fillet, which is composed largely of fine particles of gneiss.

For fertilizing bone meal (aufgeschlossencs) is used exclusively, sixteen pounds per are. In making a plot ready the trees are cut, the stumps taken out, the ground dug up and thrown into heaps in autumn, after which the bone meal is mixed with the heaps. In the following spring these heaps are spread over the ground, beds are made and sown, the seed having been mixed with lead-oxide, two pounds of the latter to sixteen pounds of seed. The depression in the bed having been made, the seed is sown thickly in them and then covered with a thin layer of fine earth that has been put through a sieve, after which the surface is pressed down gently.

Dry branches of spruce, bare of foliage, are laid on the beds for shade, and are held in place by poles laid on them. This brush is left on the beds until the plants come up through the ground, when it is removed and is not used again. Dead branches are used, because the spruce needles, which otherwise would fall on the beds, are heating in their effect and would injure the plants.

In July or August fresh humus is strewn between the rows, two cubic meters per are. 'This keeps the ground moist, hinders the growth of weeds and prevents heaving out by frost. This humus, composed of decayed needles, is found in the forest underneath the layers of freshly fallen leaves.

The plants are not watered. The foresters in these reviers claim that if water is once used during a drought the sprinkling must be continued until rain comes, or the plants will deteriorate in a noticeable degree.

The seed beds are made one and two tenths meters wide and of any convenient length. On a slope they are laid out lengthwise across the slope so that the flow of water from a heayy rainfall is checked or hindered. Side paths are twenty-five centimeters wide, and are made shallow, so that the beds will not dry out too much along their sides. The end paths are fifty centimeters broad, and are a little deeper. If the slope is such that there is danger of flooding and washing, a ditch is dug near the upper side of the inclosure, which is fenced for protection from deer.

As usual, the plants are left in the seed beds until two years old, when they are transplanted into other beds in the same nursery and treated with a fertilizer the same as the seed beds. At Oberwiesenthal the transplant beds are nearly square, three and five tenths centimeters on a side, with paths fifty centimeters wide. 


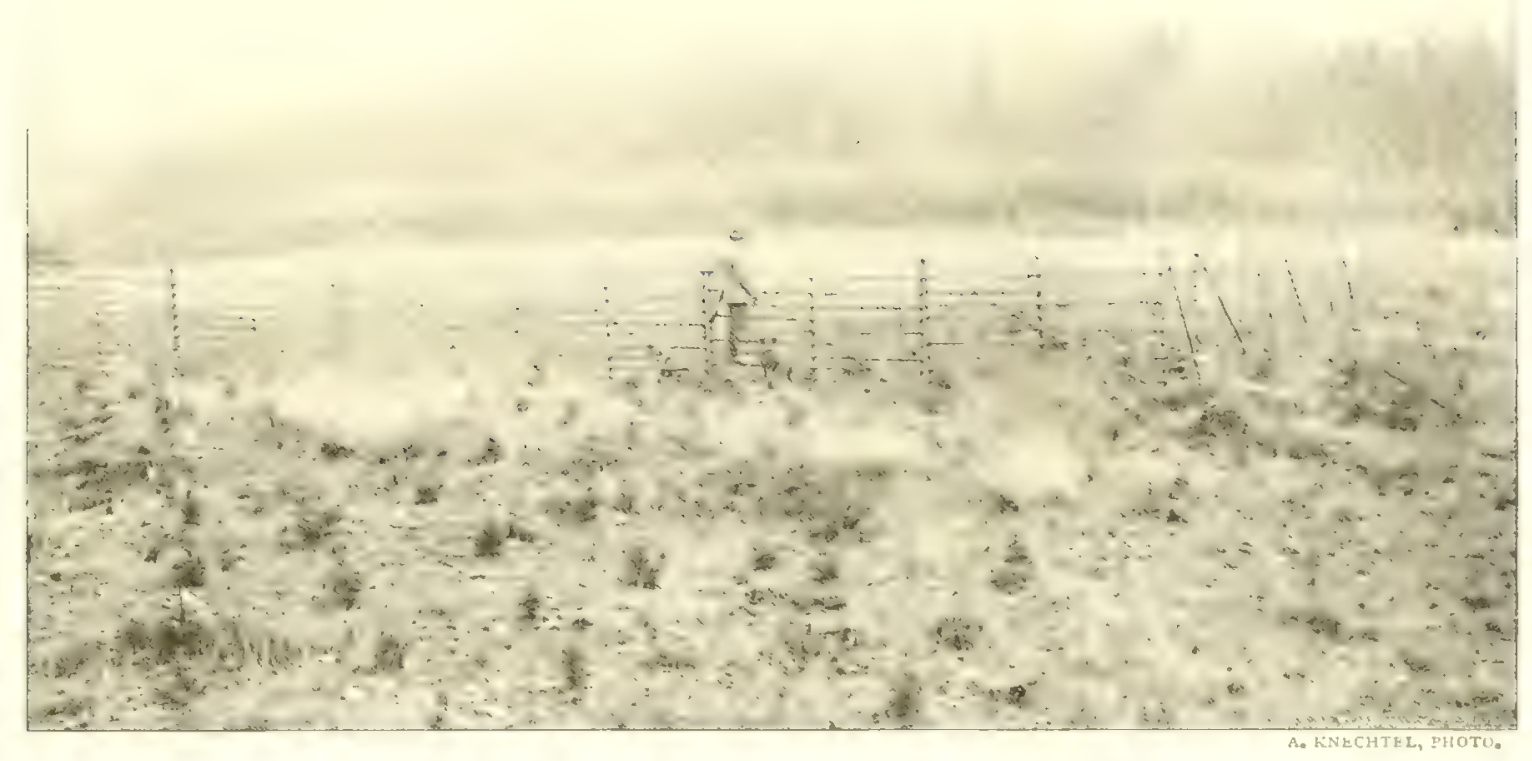

TEMIPORARY NURSERY, NORTHERN AUSTRIA.

THF GROUND OULIIME THE FENCE IS ILANTFI, WITH FUUR-YFAR-OID TR.ANSPLANTS.

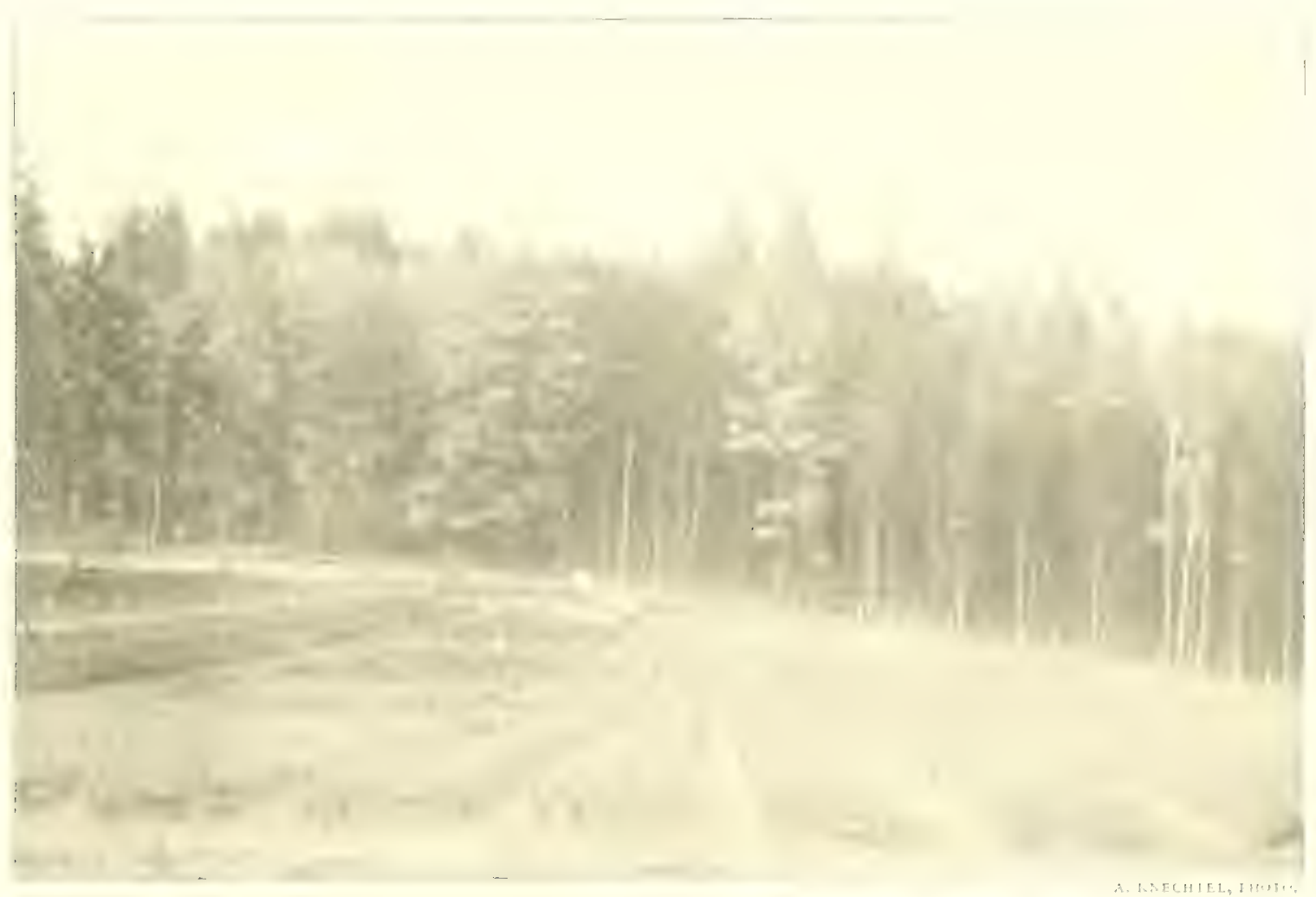

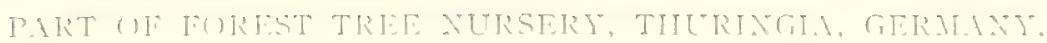

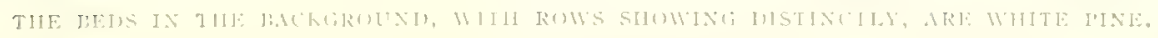



Square beds are very unusual in European nurseries, althoug in some of the commercial nurseries in ciermany lange areas filled with transplants maly be scen in which there are no waths.

$A$ spate is used to take up the seedlings for transplanting. It is shoved down between the rows, then pressed upwards, after which the plants are aently and carctully remesed ly the workman with his fingers and plited in a box-like frame matle of slats. The seedlings are rarried to the new beal, where they are set out ju drills four inches apart and the earth pressed fimly by hand atound the roots. The rows or drills in the transplant lects are made at intervals of five inclues. 'The infunt trecs are transplanted only once in the nursery and are left there until they are five years old, as the climate is somenhat sove. Wreeding is necestary only twice a year, in the spring and fall.

In the Firzgebirge a plot is generally used for a nursery only once or twice, after which it is abandoned. If used a second time, bone meal and humns are applied in the same quantities as at first. The humus is not only a fertilizer, but it acts mechanically, making the soil looser where it is tos firm and fimmer where it is too lonse

Field plantations are made from the midale of . Iay until the micklle of June, the spring being late in these reviers, at they are situated 2, Soo feet or more above sea lerel. The stumps are not removed from the ground which is to be planted, but grood earth is hauled there and distributed in small heaps, and in quantities of about ten cubic meters per hectare (two and one half acres).

Transplants are taken ont of the nursery bed and heeled in. At the proper time they are hauled in a wagon to the planting ground, and heeled in again as deep as they stoud in the nursery. They are taken up again as fast as needed, placed in pails or baskets and carried to the men who do the planting. They are planted r.t meters apart, and are set in the earth that is thrown up at the side of the hole (lochugchflansuns), two or three handfuls of the good earth being packed around the roots of each. Dy this method the plants receive nourishment from the grass and sod beneath the hillock.

The preparation of the ground for a seed plot costs about $2 z$ marks per are, the expense being made up as follows: Clearing and digging the ground, io marks; bone meal, r. 20 marks; seed, I. 20 marks; making the beds and soming the seed, 5 mark: covering with brush, 2 marks; lead oxide, o, xo marks; spreading humus, 3.2 marks - or about 85.50 for a plot 33 feet square. These figures may seem rather higl, but they were furnished by the oberfirster from his account book.

Transplanting costs: Digging over the ground in antumn, 10 marks; bone meal, r.2 marks; making beds, 3 marks; transplanting, Io marks, and humus, 
3.2 marks; total, 27.4 marks per are, or about $\$ 6.75$ per area of 33 feet square. Removing the plants from the nursery and setting them out in a plantation costs about $\$ 4.25$ per 1,000 plants, and to grow the trees in the nursery, ready for planting; about \$1.75 per 1,000 .

\section{Thrringia.}

At Eisenach, in the Thuringian Forest, there is a revier of about II,000 acres in which there are six permanent nurseries, each in the vicinity of the planting grounds where the young stock will be needed.

The soil is fertile, being composed largely of disintegrated gneiss and feldspar. The nurseries are located on gentle slopes, where the plots can have a northern or eastern exposure in order to avoid so far as possible any injury from frost, and preferably on land from which a growth of beech has been removed. In many of them sufficient space is mantained between the sides of the enclosure and the forest so that the ground will not be shaded by tall trees. Protection from wind is deemed unnecessary.

In preparing the plot the trees are cut and the stumps taken out. The ground is spaded to the depth of one foot, so that it may freeze and pulverize in the winter. In the spring it is again dug over and beds are made, thirty-nine inches wicle, with narrow sidepaths one foot in width.

Fertilizers are not applied for two or three years. Then humus and rich earth are mixed with the soil immediately after the plants are removed. Seed is sown as soon as the danger from frost is passed, about the last of April. The coating of the seeds with red lead is deemed unnecessary here. The rows in the seed beds are four and one half inches apart. A narrow slat of wood, pressed into the earth with the foot, is used to mark the rows and make the depression in which the seeds are placed.

Spruce is sown twice as thickly as pine and about one fifth of an inch apart. Larch is sown as thickly as spruce, because fifty per cent of the seeds do not germinate. Spruce and larch seed is covered to a depth of a quarter of an inch with humus or sand, or with a mixture of both, while pine is sprinkled with it so lightly as to barely hide the grains from sight.

Branches of pine are then laid on the beds; but spruce brush is not used, as the dead needles, falling on the ground, are liable to become heated and thus injure the seedlings. When the plants appear and are a month or so old, the branches are placed upright for shade. These are taken off in a dry time to allow the night dew to refresh the plants, and are removed entirely when the seedlings are strons enough to do without shade. 


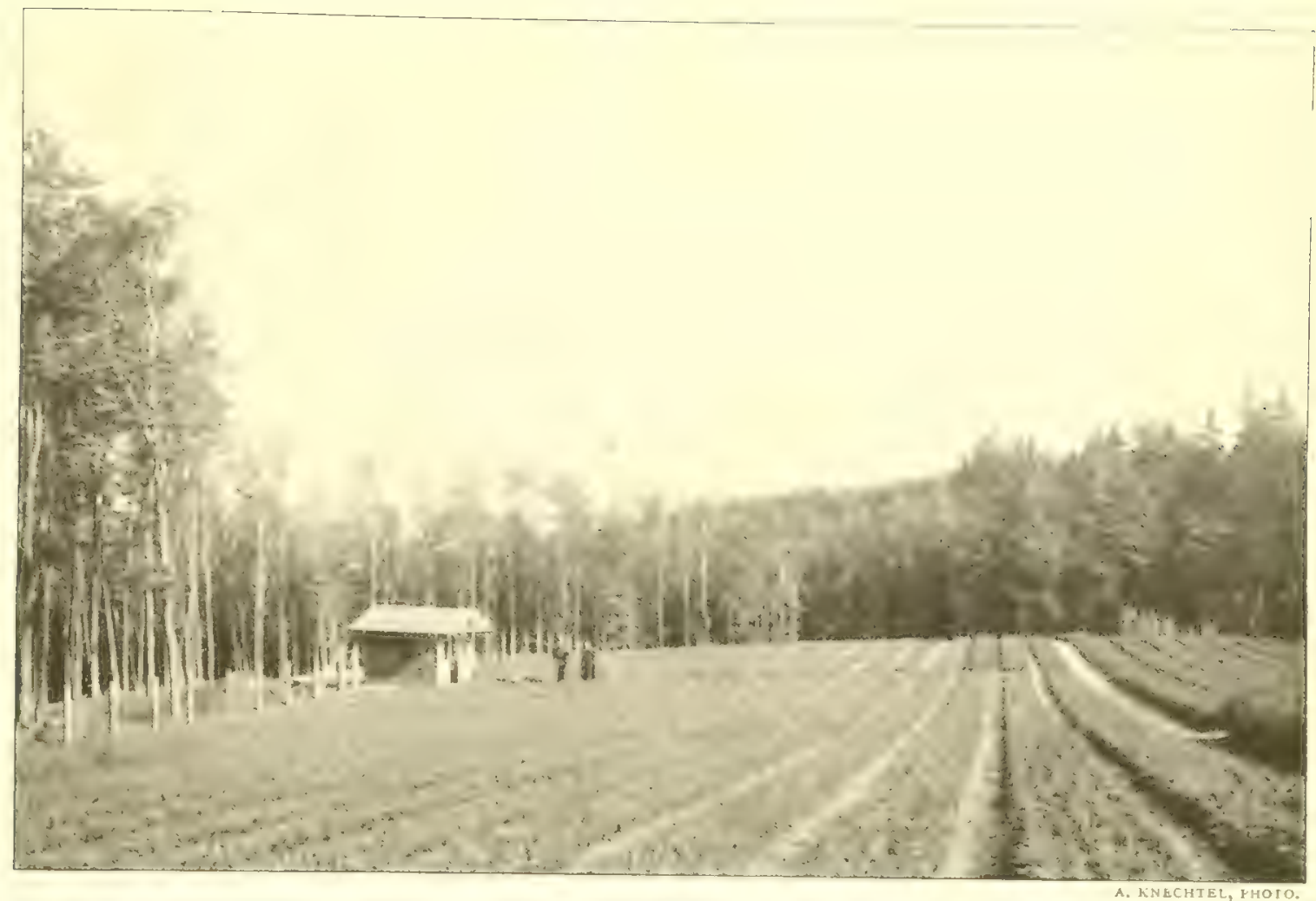

FOREST TREE NURSERI IN THE THÜRINGER IVAID, SAXE-GOTHA.

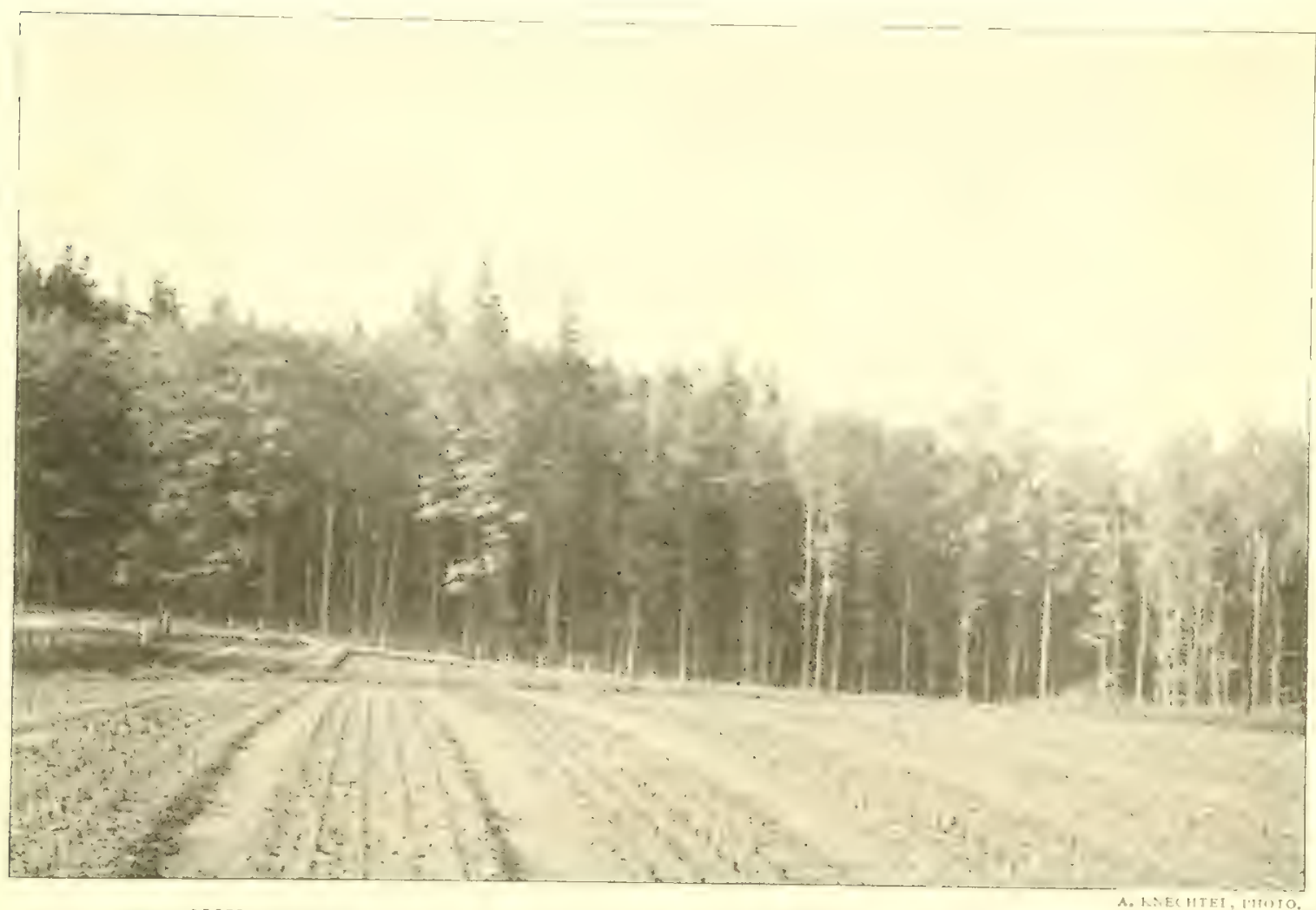

NURSERY I'INTED EXCLUSTELY WITH NORIVAY SPRUCE. 

Ammoniated superphosphate is scattered broadcast over the beds in June, twenty grammes per square meter, preferably just before a rainfall. It may be addect a second time a month later, but tusually this is not necessary. In antum moss is laid between the rows to keep the seedlings from hearing; if a supply of moss cannot be obtained conveniently, dead leaves are used for the same purpose. This covering is removed the next spring, ats soon as the danger fom frost is over.

Seedlings are transplanted when one year old, as they grow better than wi, ain left in the seed bed until they are two yeats okl, and the transplanting i.; l.... expensive. The seedlings are put into water when lifted from the seed bert tu prevent them from drying out in any degree whatever during the transfer. They are set out in the transplant bects two and one half inches apart and in rows five inches apart, just wide enough to permit the une of a hoe in weeding. They are left in the transplant bed two years; but if they are to be used in a plantation on errassy land they are held there one year more, or until they are four years old.

'The nursery near Annathal has a rectangular area of roo by 1 s s feet, sloping slighty to the southeast. The natural soil is a fertile loam, enriched by a liberal admixture with forest humus and supplemented annully with mineral fertilizers.

In the ground plan the beds are laid out sixty-five feet long und three and one guarter feet wide. A walk, three feet in width, runs across the micklle of the plut and around its sicles at the fences. Long paths, twenty-two in mumber and a foot wide each, scparate the beck, with one wide path down the middle.

'The seedlings in the germination beds, one and two years old, * are in rows running across the beds, the seed having been sown in furrows on depressed lines, not bradcast orer the entire surface as practiced in many European nurseries. But the transplunts are set ont in roms running lengthwise of the berls, six roms in a bed. The conferous species propagated in this nursery consist entirely of Norway spruce and Soutch pine. In a small portion of the enclosure there are some thrifty broad-leared plants-horse chestnut, European alder and speckled alder.

Another nursery, in an adjoining range on the road to Liebenstein, has an areat of $x 20$ l,y 150 feet, and is situated on ground sloping to the south, where it is bordered on that side by a clearing of ten acres or more. The other three sides are closely hemmed in by a dense forest. The beds are three and one quarter hy fifty feet, containing five rows of plants, lengthwise. mostly Norway spruce. Quite a large area, comparatively, is uccupied by sycamore maples, three years old.

In making a forest plantation in Thuringia the transplants are set ont by women mostly, who work for one and one half marks per day of ten hours. The

* Seed heds are made each year. 
plants are placed in the field at a cost of one pfennig each, including all incidental expenses. They are planted at intervals of one meter, or 10,000 plants per hectare -about 4,000 Ier acre.

Nost of the nurseries in the Thüringer Wald are small, each with an area of less than one acre. But at Ruhla there is a permanent one of two and one half hectires (six ancl one quarter acres) planted entirely with Norway spruce. In fertilizing, four centners (four hundred and forty pounds) of Thomasmehl and two centners of kainit are used for one morgen or quarter hectare. After the seeds have germinated in the seed beds ammorated superphosphate is strewn between the roms

The seed is sowr: by hand, about the end of May, in drills along the beds so that the plants can be protected with moss in the late autumn. The seed is sown thickly. No screens are used. The seedlings stand in the seed beds until two years old, when they are removed to other beds, where they remain two years more. As a general rule, four-year-old transplants are used in making a plantation.

\section{Prossia.}

The forest at Fricclrichsruh, near Hamburg, covers IS,750 acres, divided into eight reviers. The eight nurseries necessary for the annual planting occupy, in all, four hectares, or about ten acres of gromnd. One of the best of these is situated about two miles from the railroad station at Friedrichsruh, in the Bismarck Forest, a large tract of woodland presented to the German Chancellor by the government in recognition of his services in the Franco-Prussian war.

This nursery has an enclosure of 200 by 150 feet, is on level ground and is surrounded on all sides by an old forest, mostly beech, which comes close to the fence.

The coniferous plants raised here are mostly rottanne, with a few beds of Dinglas spruce. About one fourth of the area is devoted to broad-leaf plants, the greater part of which are pedunculate oak. There is no arrangement for screening the seed beds to protect them from birds; but a stuffed hawk, perched on a stalie close lyy, seems to answer the same purpose to a satisfactory extent.

At the Revier IInhe, in the Hartz, temporary nurseries located in the center of the planting ground are the rule. The soil, derived from granitic formations, has a natural fertility that is sufficient for the propagation of plants; but if a plot is used a second time, mineral fertilizers, of the kinds already described, are applied, with some lime ( $\mathrm{kalk}$ ) also in a few instances. Its elevation is only fortyfive feet above the sea. In both seed beds and transplant beds the rows run lengthwise. 


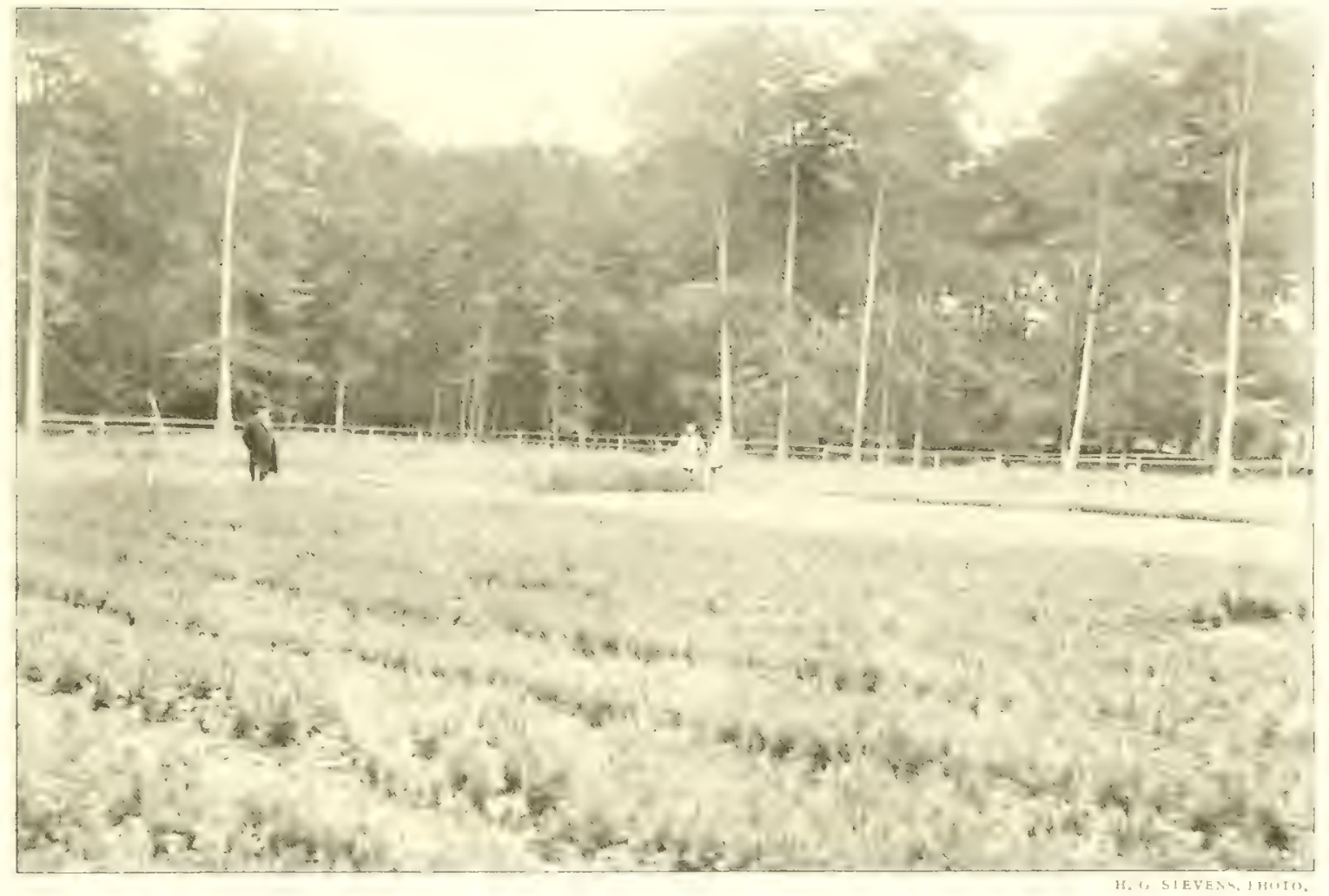

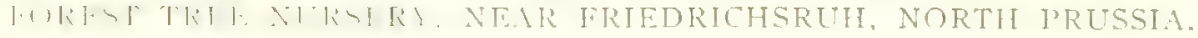

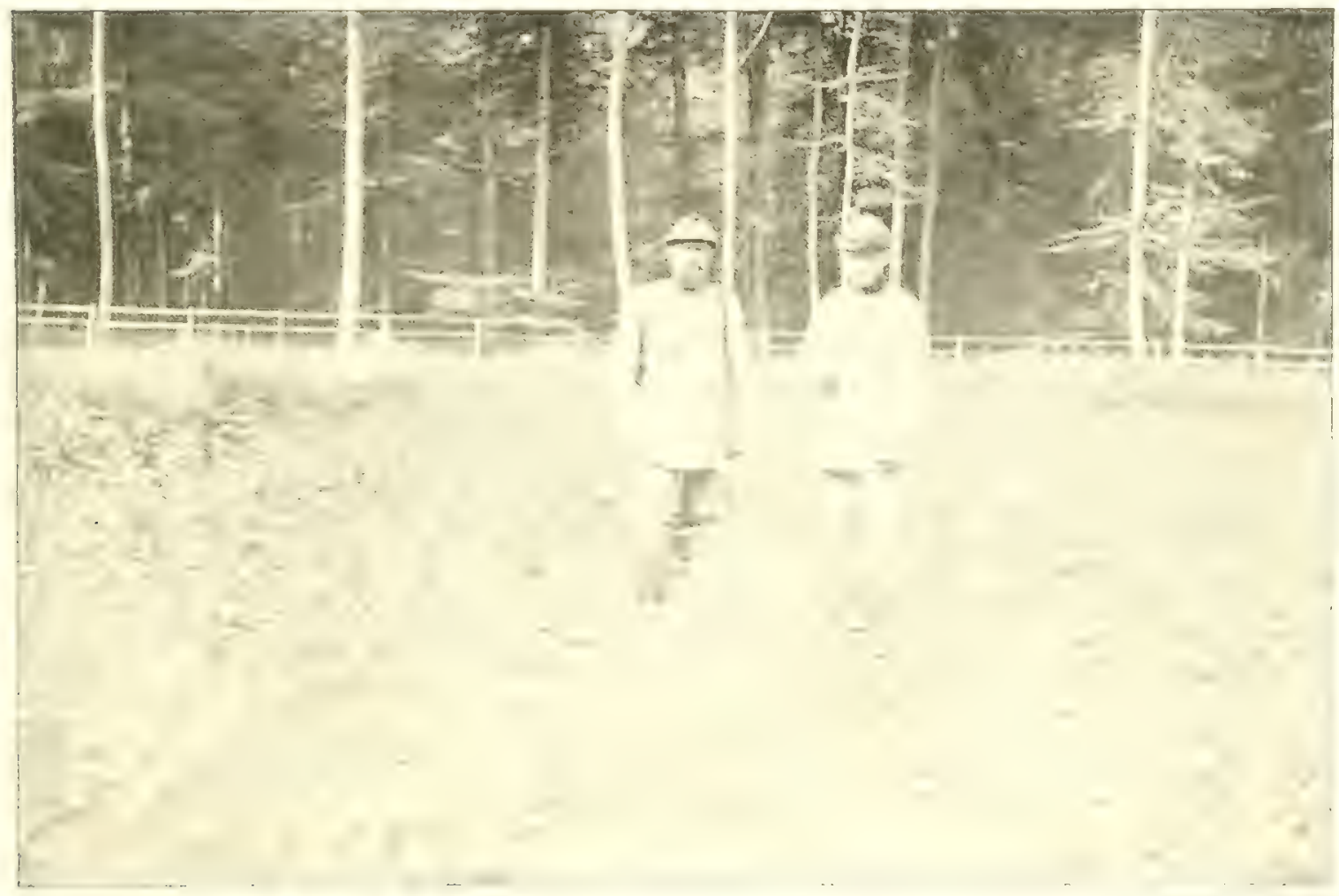



As usual, in Northern (iermany, spruce is cultivated almost cxelusively, or to al large extent. Seed, onated with leat-oxide, is thickly som in the germinating lects about the midele of May, in mows four and one half inches apurt. Brush is not laid

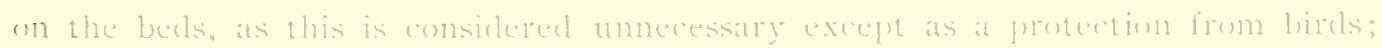
but mosis is used to protert the sodings during the winter. The latter is plated

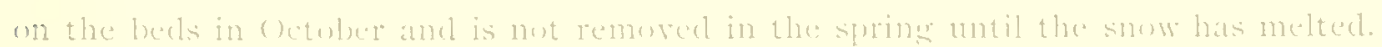

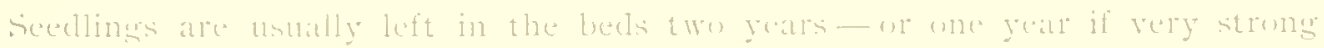
and thrifty - and are then transplanted in roms six inches alpart, where they remain two years: hut if the fichd where they are to be set ont linally is covered with grats the plants are given one year mere in the nursery beels.

The Forest of cirabum, in Mrecklenbure, belongs to the city. It has an area of 0,470 acres A forester (stadtfirster) manages it; a hunter (stallyaiger) protects the game, and an oversecer (forstaufseher) guards it arainst fire and tresplats. The orerseers atre not technically colucated men, hut are chosen from the ramlis of the workmen. The levenues are gmid inte the city treasury, after which the net income is applied to the retuction of taxes. This custom is common in most of the city and communal forests in Germany.

As the sult in the vinity of Grabow is sandy, its forests consist almost entirely of scutch jime (P'mus splecstris), a small area only being planted with

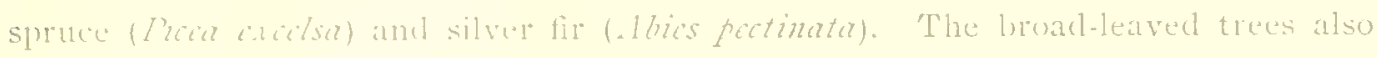
vecupy at small area, where the fertility of the soil maty indicate their 11 se. Int the soil is very peore, to a dreat extent consisting of a light colored sind which, even when damp, will not cohere if squeezed in the hand.

The nutsery is located at an altitude of 335 feet. In smmmer the temperature rises as himh ats thirty-two degrees (Reammur) in the sun, and twenty-fotw decrees in the shate: in winter it falls as low as twenty degrees below zero, same standard. The winters, howerer, are mild. The first frost occurs alunt the middle of Norember, and freezing weather is liable to last until the midule of April, with an occasional frost in May.

The seed for the nursery is generally purchased from commercial dealers, mostly from a seed house in I anmstalt. The seed beds reduire a large amount of mineral fertilizers, whing to the barrenness of the natural soil. For this purpose the forester nses Thomats meal, sixteen per cent citrates, in quantities of 880 pounds per hectale: (2! acres); carnallite, about 2,200 pounds per hectiare, and slaked lime, 6,600 punds per hectare. These compounds are mixed with fine turf, scattered thickly over the wround in winter and in the following spring are worked thoroughly into the suil. The turf is also strewn between the seedlings in the second summer of their growth. 
The Grabow nursery has an area of about half a hectare. The beds are laid out forty inches wide, and of any convenient length. The sidepaths are one foot, end paths thirty-two inches, and wagon roads ten feet in width.

The seed is sown from the fifth to the fifteenth of April, in rows about four inches apart and so thickly that the grains touch one another in many places. Sowing in rows instead of broadcast is done to facilitate weeding. The seeds are covered, about half a centimeter deep, with natural soil, unfertilized, which is not pressed down as done elsewhere in many instances. Scotch pine is usually sown first. No screens are used; but the beds are sprinkled daily in time of drought, enough water being used to moisten the ground thoroughly.

Scotch pine is left in the seed beds for one year only, after which the seedlings of this species are sent to the plantations. If left in the seed beds after they are one year old the crowded condition of the plants induces the fungal growth known as "schitte." If, however, the plants are needed for a plantation on grassy land, the seedlings are transplanted into the nursery beds, set out there eight inches apart each way, and allowed to remain another year before their removal to the field.

\section{fjàvaria.}

The forests in the Spessart are composed so largely of oak and beech that in this region the proportion of nurseries is not so large as elsewhere.

In the Forstamt Hain the plots are about one eighth of an acre each in size. In one of these, near the village of Hain, various coniferous species are grownwhite pine, Norway spruce and larch predominating.

The methol by which the beds are covered for winter is somewhat peculiar. Green branches of silver fir are used for this purpose. The beds containing white pine yearlings have each a pole fixed along the center at a height of one foot above the ground. Long branches are laid against this, with their lower ends resting on the paths between the beds. The white pine and Norway spruce, two years old, have twigs laid between the rows. The Norway spruce, one year old, is covered with the branches laid flat upon the bed, entirely covering it. The larch is left uncovered through the winter.

The nursery lies almost level. It is protected from deer by a fence of woven wire with a round top-rail, above which are two strands of barbed wire. In its minor details the management is the same as that at most other nurseries in Germany.

The methods prevailing in the various nurseries as described here will give a fair idea of the technique employed. Further examples might be given, but they would offer no additional information and would involve unnecessary repetition. 


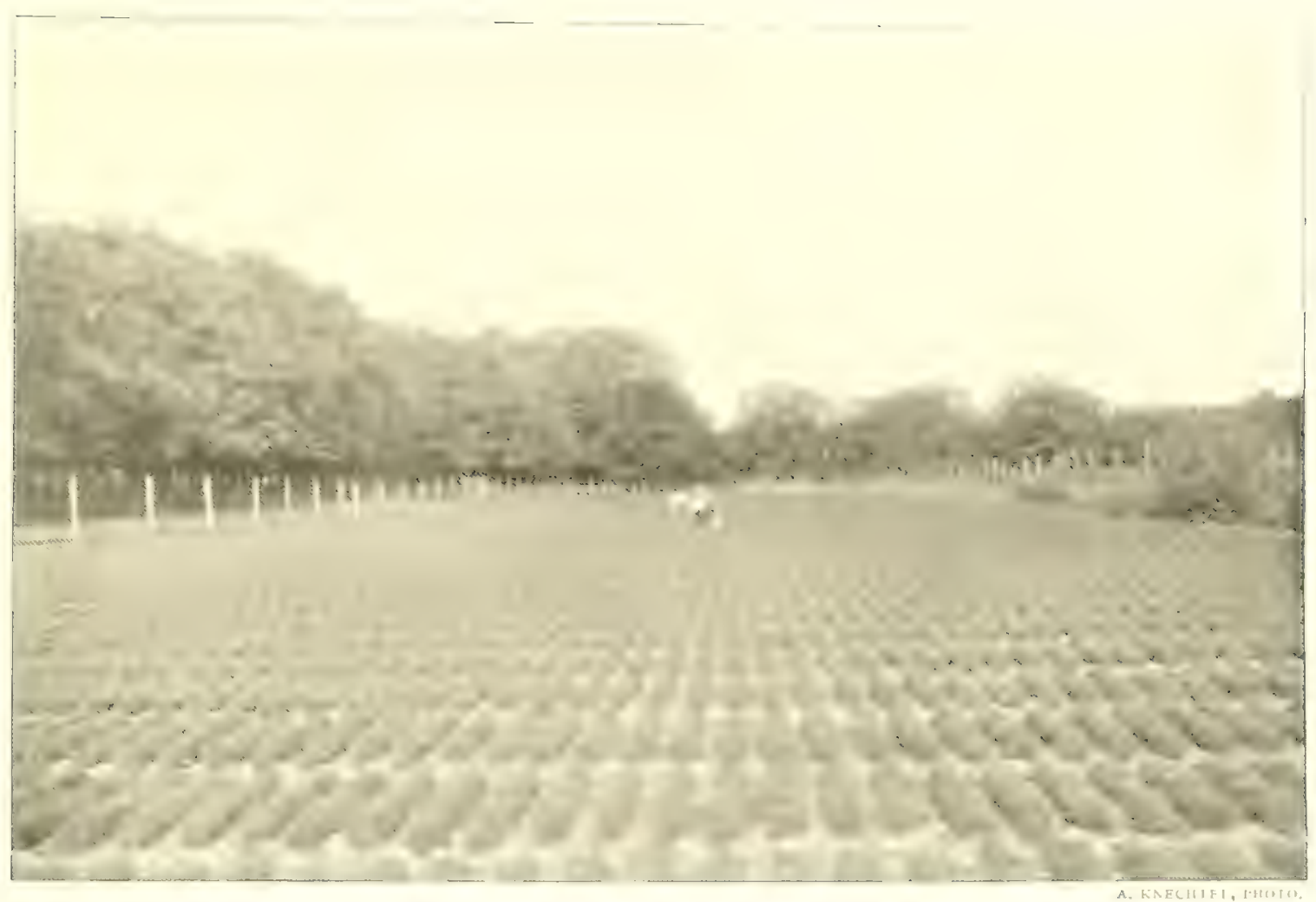

WEEITNG TRANSHLANT BEI)S (IF SCOTCH PINE.

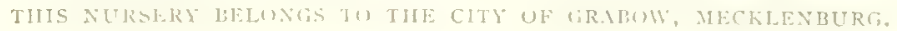

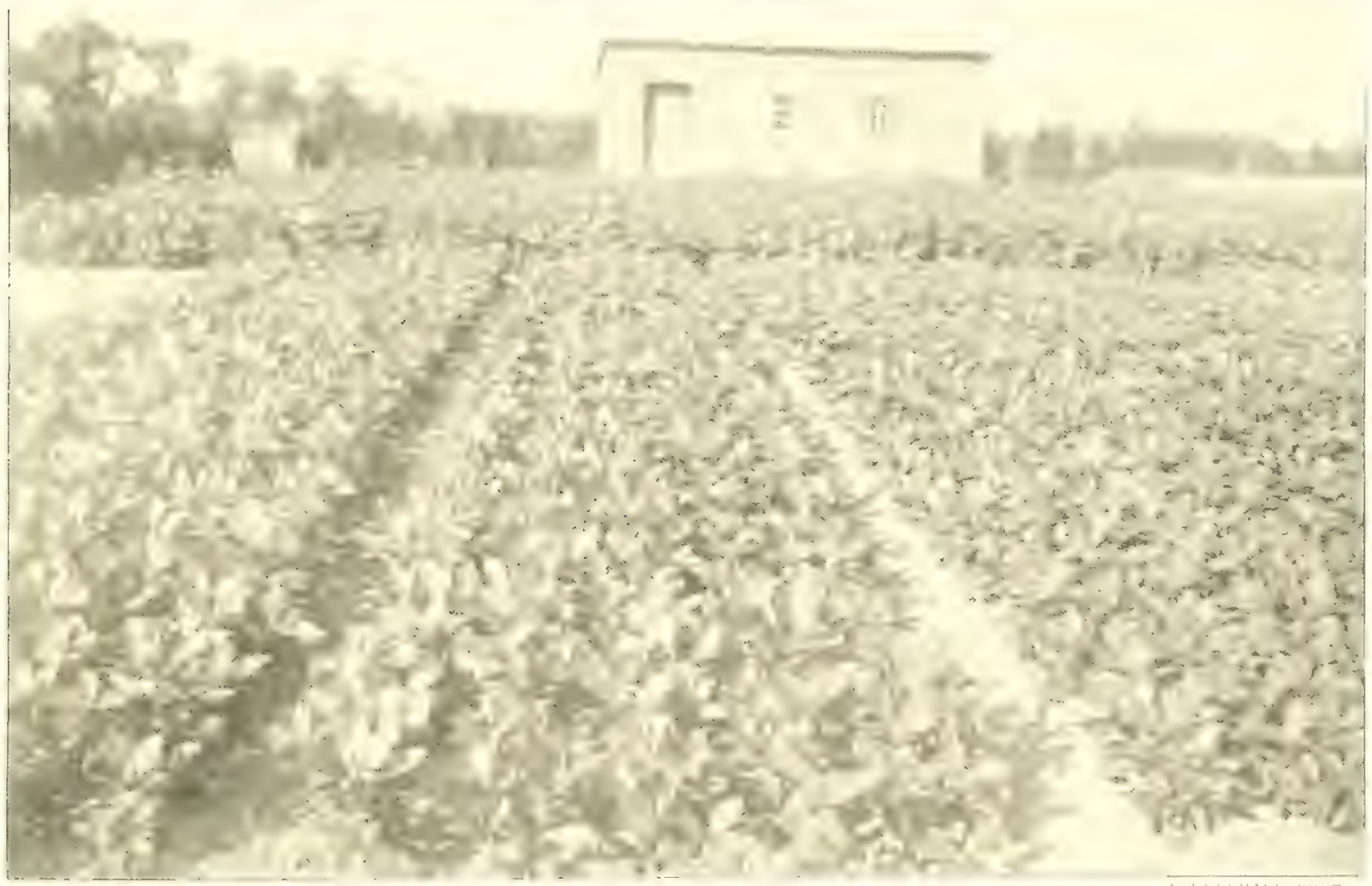

li()REL TRLE NURSERT, GIRMINY.

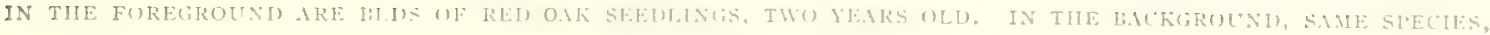





\section{In Giencrat.}

I3y way of smmmary it mas be said that, in general, the following methods are observed:

In locating a nursery mo ereat importance is attached to the question of expesure or stope, the site heinge setereted with reforence to reasoms that are more essential in commetion with the manatgonent of the revier. Neither is the altitude taken inte ansideration, as numseries may be found everywhere, from the low countries at seat level up th the monntain forests of the Apenmines or Feseces 3,000 foet abue tide. The lowation may be determined by the nearness of water, which mat le needed for sprinkling the beds in time of droughte or for irrigation. Eut the use of water is averded as far as possible on acoount of the cxtra cxipense, and because, as chamed by some, that when once resorted to it must lese continued.

Siguare wrectangular enclusures are generally made in order to secure a better greund plan, regularity in the form of the beds, and to conomize in fencing.

In nearly every instance the enchure is closely surrounded by at high forest that flimishe: climatic pontection ${ }^{1}$ at great "xtent, aldhongh in a few localities the foresters deem the shate from the trees as somewhat of a detriment. All use carefully prepared or screcnecl carth, free from gravel, stones and roxts, to which a liberal actution of compost or mineral fertilizers is made each year.

In making the ground plan long beds are preferred, with the rotrs of transplants running lengthwise. But in many nurserics the sced beds are planted with crossrows to facilitate weeding. The brodinast method for sowing seed beds, however, seems to be a favorite one. Where this is practiced the secels are distributed thickly and ats evenly as possible wer the surface of the bed, after which the top earth is raked over carefully and smoothly to cover the seeds. Another method consists in spreading a very thin layer of rich, fine eath orer the seeds insteal of raking them uncler; and it is clatimed that at more even catch is thus secured.

In order that the ground may attain the highest degree of fertility the forester often suspends operations in his nursery at intervals of four or five years, and, alfer the plants have been taken up, aliows the ground to lie fallow one season, as the exposure to rain, frost and snow has a recuperative effect on the suil, ciood results are further obtained by using the ground one season for an agricultural crop, in the cultivation of which manure is used; and there is in addition a beneficial working or division of the soil

The size and number of the nurseries under any one management is proportioned to the area of the plantations to be made. If two-year-old seedlings are 
to be used in the fieldwork, set out at spaces of four feet each way, the nurseries for this purpose have, as a general rule, a combined area equal to one per cent, or less, of that of the planting grounds. Schich says one half of one per cent.* But if four-year-old transplants are to be used the nurseries must necessarily have a larger area, one which in their aggregate will be equivalent to four per cent of that of the plantations. This percentage, however, applies to coniferous species only. Iroad-leaf plants, which are usually set out at wider spaces, require in much larger percentage of area for their propagation. An enclosure of two acres, after setting apart enough ground for seed beds, will furnish each year about r 38,000 four-year-old transplants of coniferous species, the number varying somewhat according to the space allotted to paths and roadways.

A nursery may be permanent or temporary as forest conditions may require. The latter is made in some instances merely to supply plants for some particular locality, after which, being no longer necessary, it is abandoned. If the plot will not be needed again for many years it is allowed to grow up to a young forest, some of the taller and more promising transplants being left in the beds at proper intervals for this purpose.

In most nurseries screens are used for protection against heat and frost and for protection against birds; and the beds are covered during the winter with moss or litter to prevent the seedlings from heaving. 13ut the practice in these respects varies with the species and according to the climate or soil.

\section{Protection from Decr.}

Although every nursery is surrounded by a fence or hedge to protect the stock from the deer, there are often large areas just outside the enclosure, freshly planted with four-year-olds, to which these animals have access. If the leaders on the plants are cropped by deer or cattle, the young tree is retarded in growth and is liable to become distorted in shape.

At a nursery in 'lhuringia a large area just outside the fence was recently filled with five-year-old transplants of Nomw spruce. To prevent the deer from nipping the leaters, for which these animals have a decided partiality, each plant had a sharp tin guard bent around the tip. (See illustration.) These tins before using are flat, one and three quarter inches long, one half an inch wide, and notched into four points at the top edge. This strip of tin is bent into a square, each side having a print, and slipped on the leader so that the points projcet above the tip. They are bought by the thousand, and are placed on the

\footnotetext{
*Schlich's Manual of Forestry. Vol. II, p. 99.
} 
plants at a merely nominal expense. As a deer nips at the leader first instead of the side shorts, its sensitive nuse receives a pricking that induces the animal to desist immediately from further effurt.

This device has proved very effective. But the tins fall off in time, become rusty, and when the barefooted women and children who work in the nurseries and plantations step on one of them lockjaw is liable to ensue. Deaths from this canse have occurred so frequently that some foresters will no longer permit theil tise. A forstmeister at Eiscnach, who deprecated their nse strongly, secures protection for his plants by painting the lencler on each with a mixture in which berf's blosel forms a large component, the putrid oclor proving as efilcacious and ats reptulsive to the nose of the deer ats the sharp-pointerl tin. Small

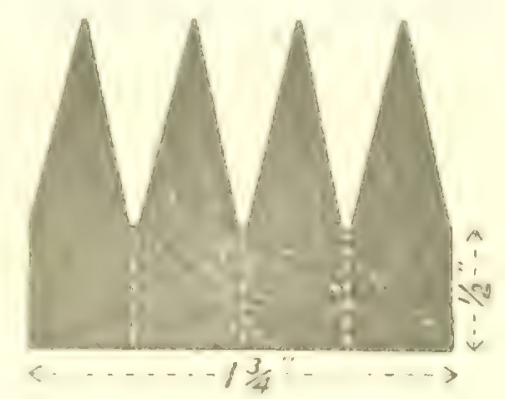

Shape of in guard hefore using. It is bent

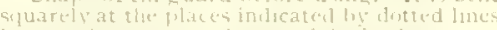

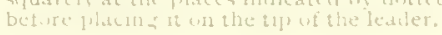

wads of cotton or tow tied to the terminal bucls are also nsed hy some foresters to protect young plants, but this methoul repuires so much time in affixing the material that it is regarded gencrally as expensive and impractical.

\section{Commercial Norscrics.}

The commercial nurseries in Gemany are remarkal, le for their wreat areas, intelligent management and economical methods. Their annual output of plants and seedings is figmed in millions-many millons"-and their superior atrantages enable them to supply, at a protit, the demand from forest reviers, and also from the smaller nurseries in Europe and America, the moprietors of which frefer w buy their seedlings instead of operating seed beds themselves. These commercial nurseries are well worth the careful attention and personal observation of any one who is interested in this branch of silvics.

The principal nurseries of this class are located at Halstenlek, in Holstein, and at Knittelsheim (railroal station at Bellheim), in the Rheinpfalz. The former is near the city of IIamburg, and the Amarican forestry student who crosses the ocean on the Hamburg line will find Halstenbel a convenient place to visit in pursuing his studies. The latter is not far from the northern part of the Black Forest, and is easily reached from there.

* The arlvertising circular of one frm this year showing the number of plants ui each species for sale indicates a stock on hand of $56,959,000$ seedlings and transplants. 
There are several firms at Halstenbek engaged in this business one of them having 200 acres or more laid out in beds, or large plots without paths, with an annual product of several million plants. They supply the managers of State. communal and private forests who have no nurseries of their own, or who find that they can purchase their plants cheaper than they can propagate them on their own reviers, or who may need an extra supply at times in addition to that raised on their own land. Shipments are also made to America, both to foresters and nurserymen. The latter import one and two year old seedlings, and set them out in their nurseries.

A visit to the commercial nurseries of Germany, and an observation of their immense annual output, will give some iclea of the great extent which the planting of artificial forests has attained throughout Europe. It indicates clearly the practical value of the system and commands the attention of American foresters, who will find in it a sood precedent for similar work at home.

A notable feature of the business at these places is their large sales of two. year-old seedlings and three-year-old transplants. The demand for four-year-old transplants is comparatively small, due largely to the extra price and greater cxpense of packing and freight.

The three-year-old plants may be seedlings, or yearlings that, having been transplanted, remained two years in the beds; or, two-year-old seedlings that were taken up and given one year in the transplant beds.

The prices of coniferous plants at the commercial nurseries, delivered free on board cars at the nearest railway station, are about as follows:

SPECIES.

White pine, once transplanted

White spruce, once transplanted

Norway spruce, once transplanted.

White pine, once transplanted

Norway spruce, once transplanted.

Douglas spruce, once transplanted.

Larch, once transplanted

Scotch pine, once transplanted

White pine seedlings

Larch seedlings

Norway spruce seedlings

Dotiglas spruce seedlings

Scotch pine seedlings. \begin{tabular}{l|l|l} 
Age, years. & Inches, & Per 1000.
\end{tabular}

\begin{tabular}{r|r}
8 to 15 & $\$ 275$ \\
8 to 16 & 250 \\
I0 to 18 & 250 \\
4 to 6 & I 75 \\
6 to 12 & I 75 \\
8 to 16 & 550 \\
I6 to 22 & +50 \\
4 to 6 & I 25 \\
3 to 4 & I 50 \\
6 to 15 & 200 \\
4 to 12 & 75 \\
5 to 12 & 300 \\
2 to 3 & 50
\end{tabular}




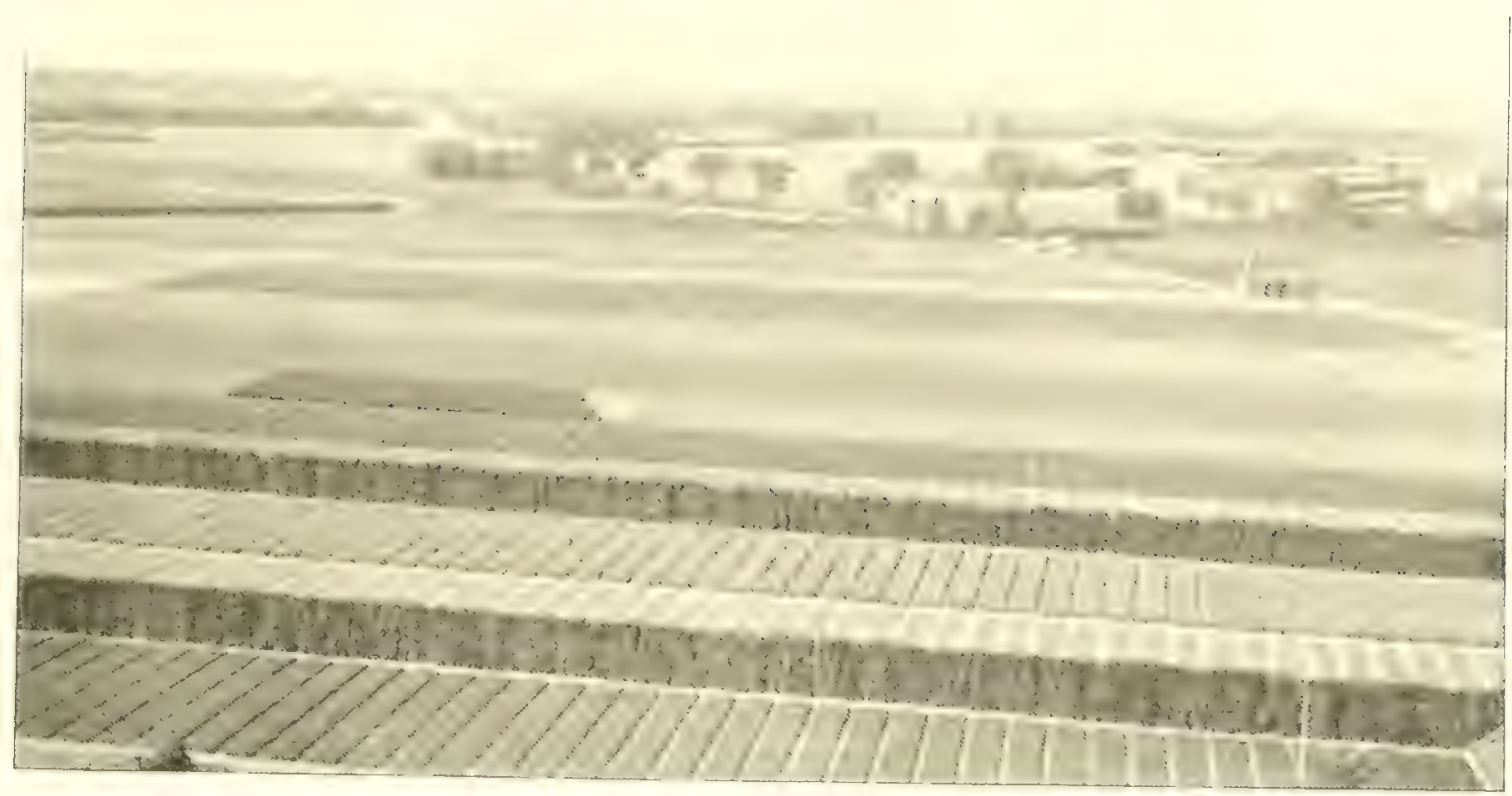

COMMERCIAL NLRSERY, HALSTENBEK, HOLSTEIN.

NOTE THE IISDIIS OF WHTE CEDAR, TO SOREEN THE BEHS FROM WINI),

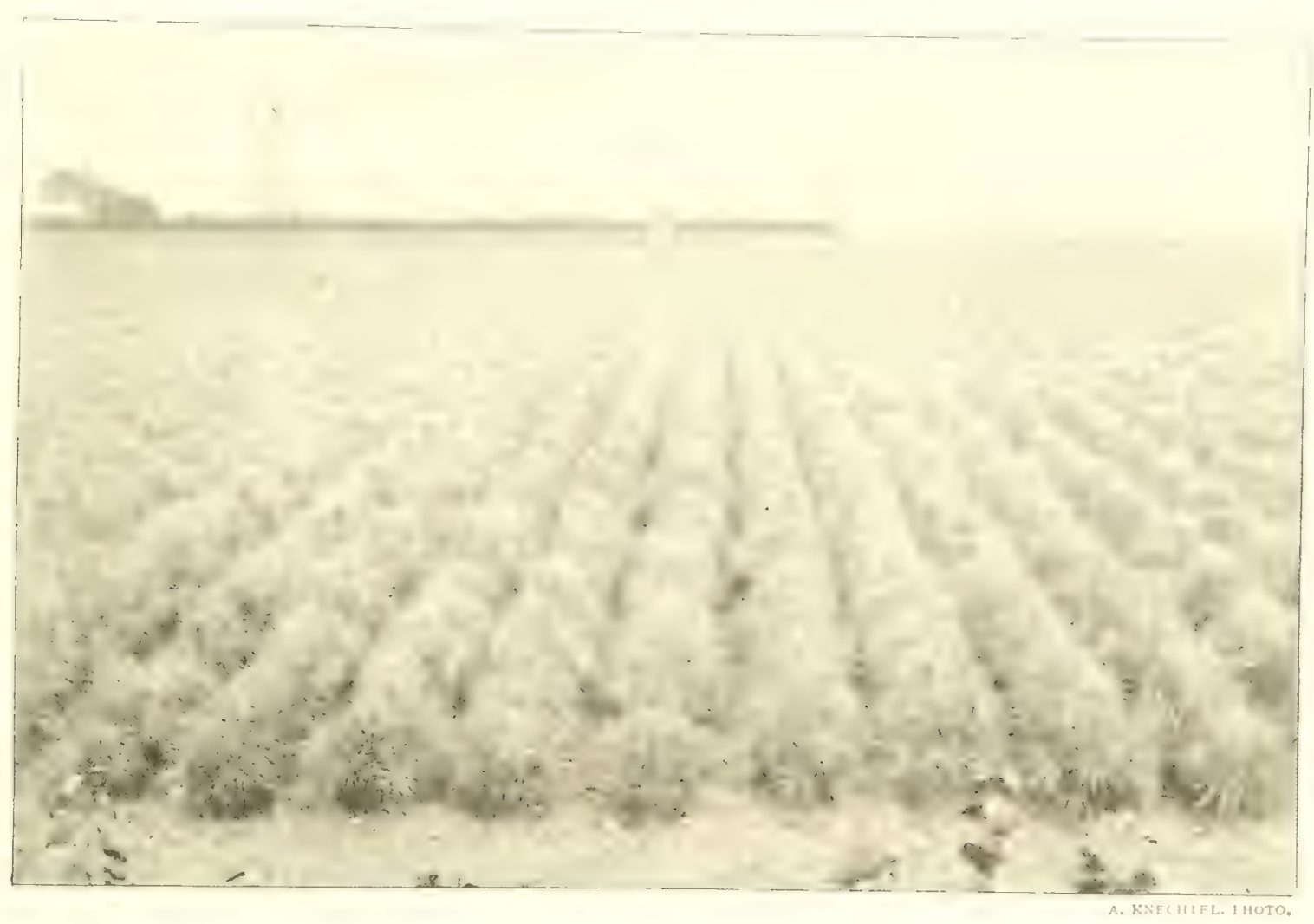

FIELD OF WHITE PINE, FULK IEAKS OID, TR.NSPIANTED. 

For large orders $(50,000$ to 100,000$)$ a satisfactory discotunt is made from the above figures; lut the price-lists of the nurserymen vary at times, influenced by a surphus stock or scarcity of the farticular species quoted. The plants, wrapped in ramp moss, are packed for shipment in large baskets, or in crates onnstructed of open willow-wots, and an extra charge is mote for packing and packages. (On shipments to the United States there is a tarifi of twenty-five per cent ad valorem, which together with the freight and the risk in transpurtation - the lone time in which the plants are packed-renders an importation a somewhat doubtful expedient.

The methods employed in the commereial nurseries are substantially the same as in the nurseries belonging to the forest reviers; but more attention is paic to minor details. The supply of seed, however, is purchased from salesmen instead of collecting it from the forcst. 'The sceels of all needle-trees are kept during winter in sacks, stored in a cond place, but the seed is not mixed with sand ats arlvised in some textbouks. The sowing is done in April and May.

The Ifalstenbek nurseries are on level ground, at an altitule of only thirty-two feet above tide. The seed beels are mate of lolack soil - at good loam that will not fall apart if pressed in the hand. Manure from the streets of Hamburge is used largely as a fertilizer, and it is scattered over the ground in winter.

The secel beds are mostly four feet wide and about sixty-five feet long. Bruadcast sowing is the pule, in order to obtain a fuller utilization of the soil. If the seeds when tested show a high percentage of germination, they are sown so that the grains lie abune one quarter of an inch apart; if the seed is porr it is sown more thickly. The coniferons plants are not screened; but in time of drought the leds are sprinkled, some of the nurseries having installed an irrigation plant for this purpose.

White pine, Norway spruce, balsam (Ghis berlsance) and silver fir are left in the seed beds until two years old; sometimes the firs are left still another year. Sentch pine can be left in the seed bed only one year with silfety, as the plants are liable to suffer from "schiitte," a fungous disease that is developed in this species by the crowded condition of the seedlings in the second year.

White pine and Norway spruce, when transplanted, are set two inches apart in the row, if the plants are to remain there only one year; but they must be placed farther apart if they are to remain a longer time in order to permit of their increased growth. The rows are made with spaces of six inches between them, or wider if the plants are to stand there two years. These simple requirements must be observed in order to secure thrifty plants and to aroid crowding in the beds. 
Scotch pine yearlings, when transplanted, are placed two and a half inches apart in the row, and the rows are laid out ten inches apart. This wide spacing of the rows is to prevent any loss from schitte. If this species is given another year in the nursery the plants must be transplanted again and given more space for growtli.*

In Germany Scotch pine is generally taken directly to the forest plantations when the seedlings are one year old. If they are to be set out on grassy land, however, they are allowed the benefit of one year first in a transplant bed; and if the grass is thick or apt to overshadow them too much, they are transplanted twice.

From the Halstenbek nurseries white pine is often sent to the forest when two years old, untransplanted; or three years old, once transplanted, if they are to to be used on grass land. It is claimed by the commercial nurserymen that this species grows too slim and that the root system is poorly developed if left in the seed bed more than two years.

Douglas spruce, balsam fir (Abics concolor) and silver fir are protected from frost for the first two years by mats made of coarse reeds supported by long poles laid along the beds on stakes one foot in height. The Douglas spruce is protected from the wind by hedges, for which purpose white cedar is planted at one side of the beds. These hedges are used to considerable extent at Halstenbek, although they are not essential to the growth of other species. They also serve to shelter the workmen from the cold winds prevalent there in spring and fall.

The seeds of most of the broad-leaved trees are sown in March and April; but the seeds of basswood, ash and thorn are kept in "seed-chests" eighteen months before planting. 'These seed-chests are compartments made of brick, with an inside measurement of thirty-nine inches in length, twenty inches in width, and twenty inches high. They are placed out doors, partly below the surface of the ground, in rows of ten, each row surrounded by a thick hedge of white cedar. The seeds stored in them are usually mixed with sand, although this is not deemed essential, and a mat macie of straw is laid over them. With this treatment the seeds when planted germinate and come up quickly, usually in two weeks.

In the propagation of cleciduous species, beds are made about the same as for the needle-trees, and the seeds are sown in rows lengthwise with the bed, seven rows in each. The drills or depressed grooves are made with a machine; but

* While this treatment of Scotch pine may be necessary at Halstenbek to prevent disease, in American nurseries this species is left in the seed beds two years, and in the transplant beds two or three years with perfect safety, no matter how closely the seeds may be sown or the transplants placed. 


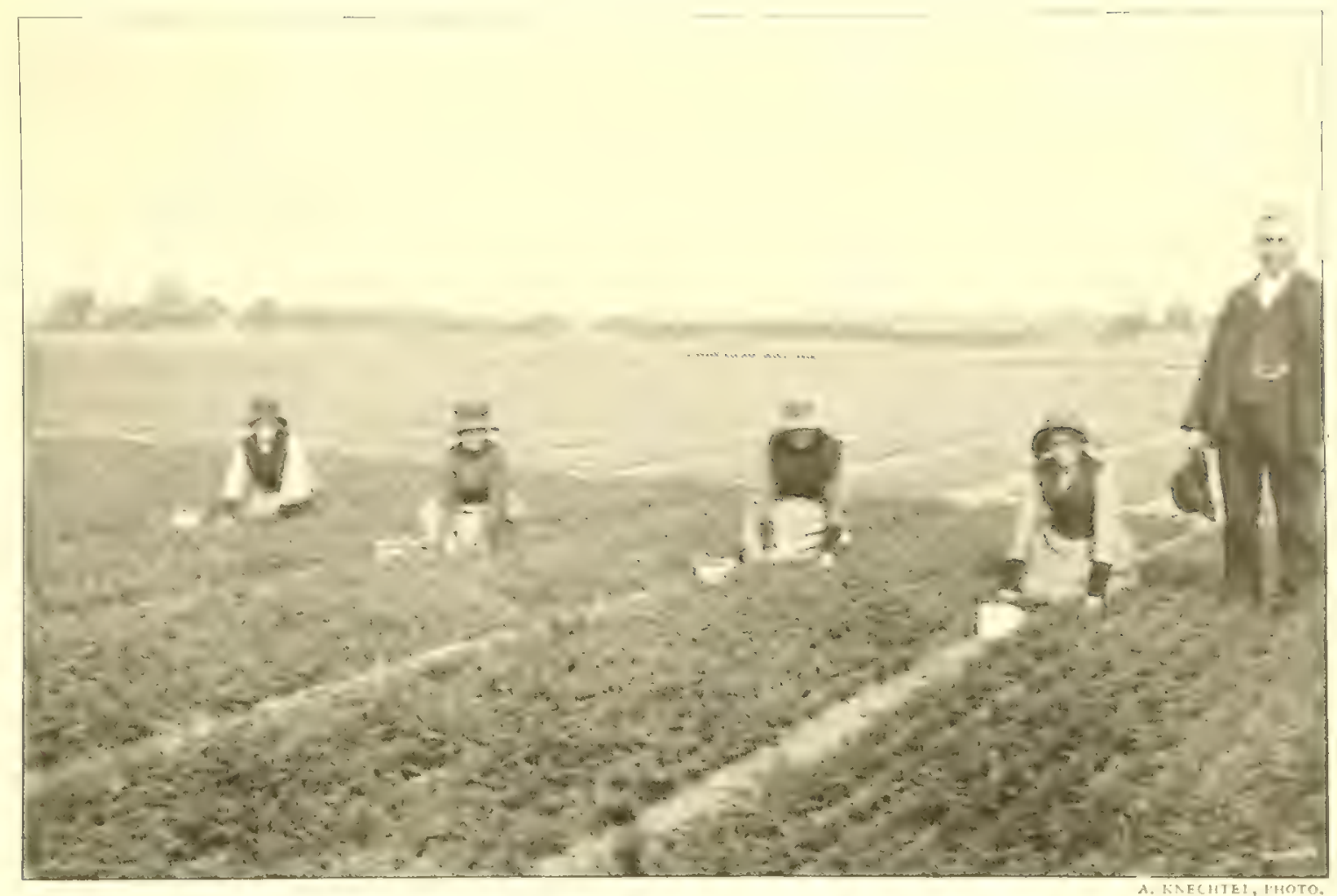

IVEEDING TRANSPLANT BEDS. CUMMERCLI, NURSERY, GERMANY.

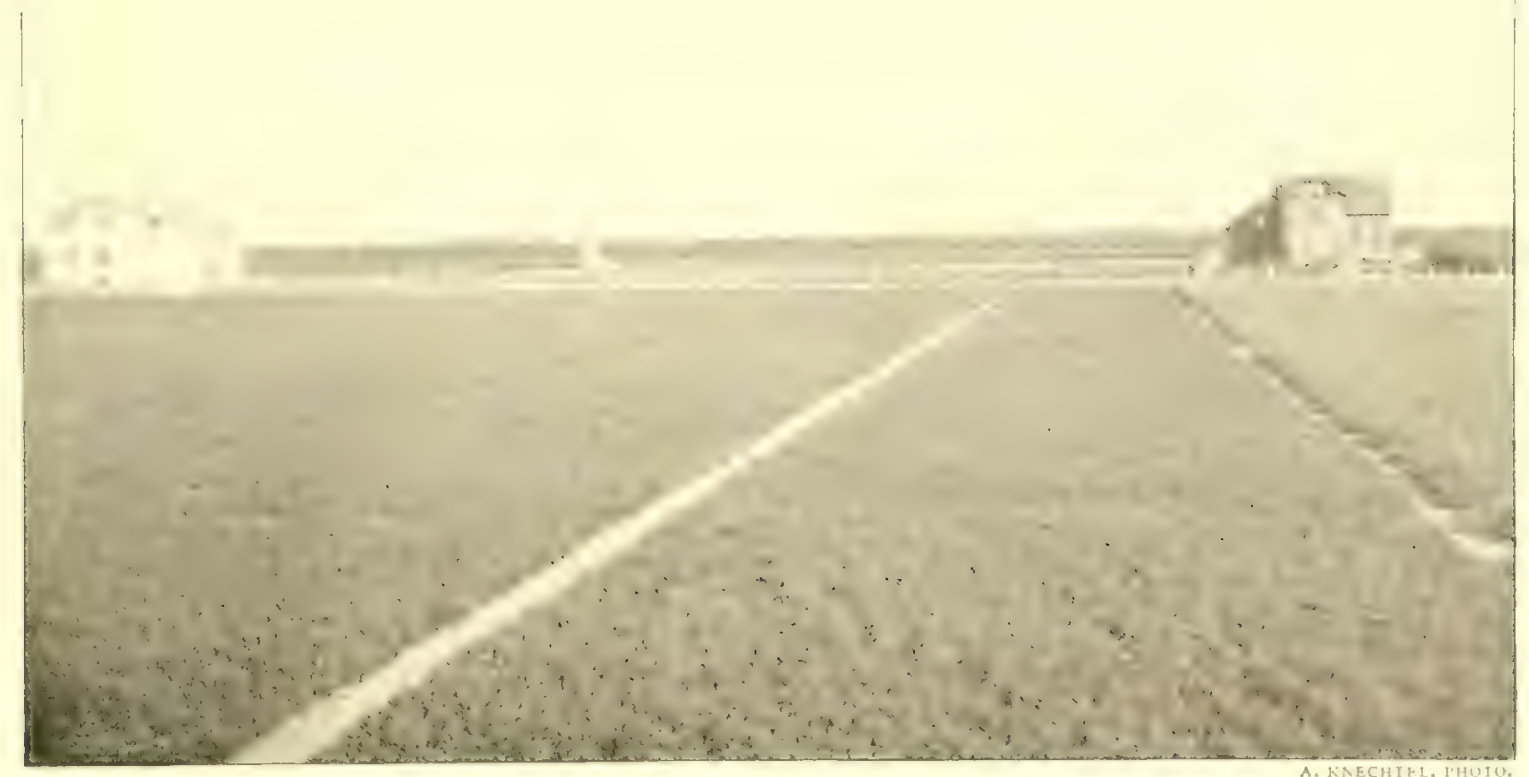

LARGE BEDS OF NORWAY SPRUCE, FOUR IEARS OLD, ONCE TRANSPLANTED. COMMERLIAL NLESERY, GERMANL, 

the seed is sown and covered by hand. The rows are seven inches apurt, but after one year the alternate rows are taken ont. The seeds are sown thickly, so that the plants will stand about four inches apart.

Needle-plants are shipped in large, cylinclrical baskets-Scotch pine, one year old, 55.000 in a basket; white pine, one year old 30,000; two years, 10,000; three years, 7,000: and Norway spruce, two years, 15,000 : three years, 8,000 . Paper is laid in the batsliet, on the bottom and around the sides, next to which is placed a layer of moss. A bunch of straw is then plited vertically in the center of the basket. The plants, which are tied into small bundles before taking them from the field, are placed in the basket with their tops towards the outside. From the center to the side of the busket three circular rows of hundles can be placed, which, however, overlap each other at one end like the shingles on a roof. Each layer of bundles is covered with loose turf before the next layer is put into the basliet. The bunch of suaw standing in the center permits the sscape of heat, the paper prevents the escape of moisture, while the moss and turf hold the water that supplies the necessary moisture during transportation.

When a shipment is to be male the plants are lifted from the beds during the day, tied in small humbles and each bundle buried lightly in the earth, this work being done usually by women. Then in the evening the bundles are rathered and hatled to a cellar where they are packed in baskets the next day for shipment. Two men pack from 3,000,000 to 4,000,000 plants (one and two years old) in a day. The baskets are then weighed, loaded on wagons and hauled to the railroal station, which at Halstenbek is cluse by the nurseries. Broad-leaf trees are put up in large bundles and wrapped in straw for shipment, the roots covered with burlap. The proprietor of a large commercial nursery at Knittelsheim, in his instructions to purchasers, says:

"Plants should be taken from the railway stition promptly after their arrival. If the cannot be planted immediately they should be heeled in, care being taken that tire routs are properly coverecl with earth. Inring qransportation, whether on the railroad or on the delivery wagons, the plants should be covered with straw or otherwise sheltered from the sum and winds. If, on account of frosty weather, they camnot be set out immediately, they should be put in a cellar in upright position close together. I'lants which arrive in a heated condition, as sometimes happens with Scotch pine, should be treated the same way. Immediate watering while stored in damp cellars must be avoided, or the roots will become rotten; and in no case should frozen plants be put in a warm room. It is also dangerous to hold a Scotch pine yearling in the land longer than necessary, as the warmth will affect it unfavorably. Shortening the roots will, in most cases, 
promote a better development of the fibrous growth. A sharp knife should be used, and a downward cut made. In trimming transplants it is sufficient to shorten the root-hairs merely and to remove the dead ones. Transplants cost more than seedlings; but, in most cases, it is false economy to buy the latter. for transplants are stronger, have a better root system, and are more able to withstand all unfavorable influences."

\section{Commercial Seedsmen.}

In all nurseries, whether commercial or otherwise, a supply of good seed is an important matter. To a great extent the commercial nurseries, and many of the forest nurseries as well, obtain their seed from dealers who make a specialty of collecting, preparing and storing forest-tree seed in large quantities. Mercantile houses that deal in seeds only may be found in most any of the principal cities of Enrope. Having superior facilities, through specialized work, for carrying on this business they are able to offer better seed and at lower prices than the inursery managers can collect it.

Seerls of the principal coniferous species can be bought from any of the large seed houses in Europe at the following rates, subject to variation at times caused by a scarcity or plenty of some particular kind:

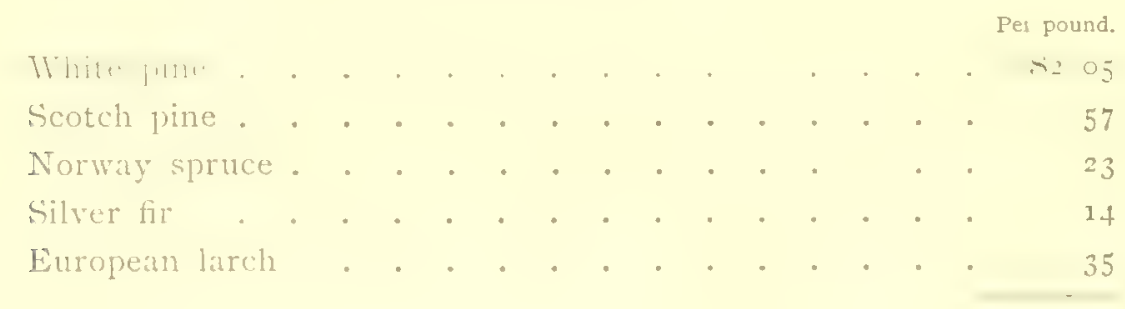

Seeds that show a rery high percentage of germination may command a slightly higher price.

Their houses in which the cones of the needle-trees are dried and the seed extracted are each furnished with a specially devised apparatus. In some of them the heat is regulated by electricity in order to secure a more even temperature and thereby avoid any overheating of the :ones, which would destroy the germinating quality of the sects. They also hove special factities for cleaning, arying and storing seed; and in every detail the methods employed are based on long experience in this special work.

In any of these seed houses may be seen some kind of device or apparatus for testing the vitality of seeds and their percentage of germination, an important 
item in the business. Still, in order to satisfy customers, official tests are also obtained by prominent dealers. A seed house in Knittelsheim advertises that its collections are tested for "purity and germination" hy the "Swiss Control Office for the Examination of Seeds," at \%urich, Switzerlancl.

Foresters who gather sect for use in their own nurseries have various wollknown tests of a simple character to determine its ralue. lint there are several government stations to which samples of stock may be sent to be tested and to determine the percentage of germination. The principal ones are located at Eberswalde and Tharandt, in Germany; Zurich, in Switzerfand, and Marialrum, in Austria.

These official tests enable the nursery manager to aroil any loss caused by sowing worthless grains, to protect himself arainst fraud on the part of unscrupulous dealers and to determine the quantity that should he somn.

If a report is needed immediately from the station, a numbler of seeds are cut open and examined for color, plumpmess, taste, oflor, etc. For cxample, the kernel of the beech and the chestnut, if all right, is white and very pleasant to the taste; that of the oak is redelish white; the maple, green; the ash, white and waxy; pine, white with a strong odor of turpentine. Conferous secels are crushed with the finger mail ujom a piece of white paper, upon which a grod seed leaves an wily stain.

If time permit the seeds may be actually germinated. The larger sorts, such as the oak seeds, are placed in vessels filled with earth, covered the proper depth, kept moist and at a temperature favorable to germination. Conifer seeds are placed between folds of hannel which are dipped into water liept at a medium temperature. There are also several forms of porous vessels made specially for such tests.

It is loned that the descriptions given in the foregoing pages, together with the illustrations accompany ing them, may le useful in calling jublic attention to the practical value of planted forests. In thmerica the reforesting of clenuded lands by artificial means - the formation of planted forests - is a duestion that sooner or later will confront our foresicrs. The student, om graduating from a forestry school, should supplement his course of study with at trip aloroad in order to see the plantations there and the nurseries which are an inclispensable adjunct to this particular system of forestry. 

LIBRARY OF CONGRESS

|||||||||||||||||||||||||||||||||||||||||||||||||

00008816943

Hollinger Corp. $\mathrm{pH} 8.5$ 